\title{
Genetic Predisposition to Breast and Ovarian Cancers: How Many and Which Genes to Test?
}

\author{
Davide Angeli ${ }^{1}$, Samanta Salvi ${ }^{2}$ and Gianluca Tedaldi ${ }^{2, *(1)}$ \\ 1 Biostatistics and Clinical Trials Unit, Istituto Scientifico Romagnolo per lo Studio e la Cura dei Tumori (IRST) \\ IRCCS, 47014 Meldola, Italy; davide.angeli@irst.emr.it \\ 2 Biosciences Laboratory, Istituto Scientifico Romagnolo per lo Studio e la Cura dei Tumori (IRST) IRCCS, \\ 47014 Meldola, Italy; samantasalvi@gmail.com \\ * Correspondence: gianluca.tedaldi@irst.emr.it; Tel.: +39-0543-739232
}

Received: 23 December 2019; Accepted: 5 February 2020; Published: 8 February 2020

\begin{abstract}
Breast and ovarian cancers are some of the most common tumors in females, and the genetic predisposition is emerging as one of the key risk factors in the development of these two malignancies. $B R C A 1$ and $B R C A 2$ are the best-known genes associated with hereditary breast and ovarian cancer. However, recent advances in molecular techniques, Next-Generation Sequencing in particular, have led to the identification of many new genes involved in the predisposition to breast and/or ovarian cancer, with different penetrance estimates. TP53, PTEN, STK11, and CDH1 have been identified as high penetrance genes for the risk of breast/ovarian cancers. Besides them, PALB2, BRIP1, ATM, CHEK2, BARD1, NBN, NF1, RAD51C, RAD51D and mismatch repair genes have been recognized as moderate and low penetrance genes, along with other genes encoding proteins involved in the same pathways, possibly associated with breast/ovarian cancer risk. In this review, we summarize the past and more recent findings in the field of cancer predisposition genes, with insights into the role of the encoded proteins and the associated genetic disorders. Furthermore, we discuss the possible clinical utility of genetic testing in terms of prevention protocols and therapeutic approaches.
\end{abstract}

Keywords: hereditary breast and ovarian cancer; gene panels; cancer predisposition; next-generation sequencing; cancer risk

\section{Introduction}

Breast cancer $(\mathrm{BC})$ and ovarian cancer $(\mathrm{OC})$ are the first and the eighth most common tumors for both incidence and mortality in females, respectively [1]. BC can also affect males, even if male breast cancer (MBC) represents less than $1 \%$ of all BCs [2-4].

As for other cancers, BC and OC are the result of a combination of both environmental and genetic risk factors. About $10-30 \%$ of BCs and OCs show familial clustering, but only $5-10 \%$ of cases are estimated to be hereditary, being associated with a germline pathogenic variant (PV) or likely-pathogenic variant (LPV) in a cancer predisposition gene $[5,6]$.

$B R C A 1$ [7] and BRCA2 [8] are the main genes involved in Hereditary Breast and Ovarian Cancer syndrome (HBOC) [9], but other genes have also been associated with $B C$ and $O C$ risk [10-17].

In the last few years, the advent of Next-Generation Sequencing (NGS) has enabled the analysis of a great number of genes with the advantage of lower costs and wider access to molecular tests for patients with suspected genetic syndromes [18].

In this complex scenario, one of the main issues is to define how many and which genes should be tested in patients with a suspicion of a genetic predisposition to cancer.

In this review, we summarize the past and most recent genetic findings on $\mathrm{BC} / \mathrm{OC}$ predisposition, grouping the genes on the basis of their penetrance, calculated on large case-control studies, and taking 
into account their function and association with genetic disorders (Table 1). The penetrance of a disease-causing genetic variant is the proportion of carriers of that variant who develop the disease, whereas the relative risk (RR) is the measure of the risk of developing a disease compared to the risk of the general population. A genetic variant is usually defined with high penetrance when the RR for the carrier is $\geq 10.0$, with medium-high penetrance when the $R R$ is between 5.0 and 10.0, with moderate penetrance when the $R R$ is between 2.0 and 5.0, and with low penetrance when the $R R$ is between 1.0 and 2.0 [19].

Table 1. List of the main genes associated with breast cancer (BC)/ovarian cancer (OC) with associated syndromes and $\mathrm{BC} / \mathrm{OC}$ risk estimates.

\begin{tabular}{|c|c|c|c|c|c|}
\hline Syndrome Associated & Gene & Locus & BC Risk * & OC Risk * & References \\
\hline Hereditary Breast and & $B R C A 1$ & $17 q 21.31$ & $57-65 \%$ (by age 70 ) & 39-44\% (by age 70) & \multirow{2}{*}{ [20-22] } \\
\hline Ovarian Cancer (AD) & $B R C A 2$ & $13 q 13.1$ & $45-55 \%$ (by age 70 ) & $11-18 \%$ (by age 70 ) & \\
\hline $\begin{array}{l}\text { Peutz-Jeghers } \\
\text { syndrome (AD) }\end{array}$ & STK11 & $19 \mathrm{p} 13.3$ & $32-54 \%$ & $18-21 \%$ & [23] \\
\hline $\begin{array}{l}\text { Cowden syndrome } \\
\text { (AD) }\end{array}$ & PTEN & $10 \mathrm{q} 23.31$ & $25-85 \%$ & NA & [24] \\
\hline $\begin{array}{l}\text { Li-Fraumeni syndrome } \\
\text { (AD) }\end{array}$ & TP53 & $17 \mathrm{p} 13.1$ & $25-79 \%$ & NA & [25] \\
\hline $\begin{array}{l}\text { Hereditary Diffuse } \\
\text { Gastric Cancer (AD) }\end{array}$ & $\mathrm{CDH1}$ & $16 \mathrm{q} 22.1$ & 39-52\% (by age 80) & NA & {$[26,27]$} \\
\hline $\begin{array}{c}\text { Ataxia-telangiectasia } \\
\text { (AR) }\end{array}$ & ATM & $11 \mathrm{q} 22.3$ & $17-52 \%$ & NA & [28] \\
\hline- & CHEK2 & $22 q 12.1$ & $25-39 \%$ & NA & [29] \\
\hline- & BARD1 & $2 q 35$ & NA & NA & [30] \\
\hline $\begin{array}{l}\text { Neurofibromatosis } \\
\text { type I (AD) }\end{array}$ & NF1 & $17 \mathrm{q} 11.2$ & $\sim 8 \%$ (by age 50 ) & NA & [31] \\
\hline $\begin{array}{l}\text { Nijmegen breakage } \\
\text { syndrome (AR) }\end{array}$ & $N B N$ & $8 \mathrm{q} 21.3$ & $12-30 \%$ & NA & [32] \\
\hline \multirow{2}{*}{ Fanconi anemia (AR) } & PALB2 & $16 \mathrm{p} 12.2$ & $44-63 \%$ (by age 80 ) & $2-10 \%$ (by age 80 ) & [33] \\
\hline & BRIP1 & $17 \mathrm{q} 23.2$ & NA & $\sim 6 \%$ & [34] \\
\hline- & RAD51C & $17 q 22$ & NA & $\sim 7 \%$ & {$[35,36]$} \\
\hline- & RAD51D & $17 q 12$ & NA & $\sim 15 \%$ & {$[35,37]$} \\
\hline \multirow{5}{*}{ Lynch syndrome (AD) } & MLH1 & $3 p 22.2$ & \multirow{5}{*}{ NA } & \multirow{5}{*}{$4-12 \%$} & \multirow{5}{*}[38]{} \\
\hline & MSH2 & $2 \mathrm{p} 21-\mathrm{p} 16$ & & & \\
\hline & MSH6 & $2 \mathrm{p} 16.3$ & & & \\
\hline & PMS2 & $7 \mathrm{p} 22.1$ & & & \\
\hline & EPCAM & 2 p21 & & & \\
\hline
\end{tabular}

AD: autosomal dominant; AR: autosomal recessive; NA: not assessed. * The percentages represent lifetime risks unless otherwise specified.

\section{High Penetrance Genes}

\subsection{BRCA1 and BRCA2}

The BRCA1 gene is located on chromosome 17q21.31 and encodes a nuclear protein involved in DNA repair, cell cycle checkpoint control, and maintenance of genomic stability [39,40]. The BRCA1 protein is a tumor suppressor acting with other tumor suppressors, DNA damage sensors, and signal transducers to form a large multi-subunit protein complex known as BRCA1-associated genome surveillance complex (BASC) [41,42].

Germline PVs in BRCA1 gene are associated with a $57-65 \%$ and $39-44 \%$ risk of developing BC and OC by the age of 70, respectively [20-22]. BRCA1 PV/LPVs have also been associated with an increased risk of $B C$ in males, which is estimated to be $1.2 \%$ by the age of 70 [43]. In addition, BRCA1 PV/LPVs have been associated with an increased risk of colon cancer [44], prostate cancer [45], and pancreatic cancer [46,47].

The BRCA2 gene is located on chromosome 13q13.1 and encodes a nuclear protein involved in repairing damaged DNA through homologous recombination (HR) [39,40]. BRCA2 protein mediates 
the recruitment of the recombinase RAD51 to the DNA double-strand breaks (DSBs) through the formation of a BRCA1-PALB2-BRCA2 complex. The BRCA2 protein contains a helical domain, three oligonucleotide binding domains, and a tower domain, which allow BRCA2 binding to both single-stranded DNA and double-stranded DNA [39,48,49].

Germline PV/LPVs in the BRCA2 gene are associated with a $45-55 \%$ and $11-18 \%$ risk of developing $\mathrm{BC}$ and $\mathrm{OC}$ by the age of 70, respectively [20-22]. BRCA2 PV/LPVs have also been associated with an increased risk of $B C$ in males, which is estimated at $6.8 \%$ by the age of 70 [43]. In addition, BRCA2 $\mathrm{PV} / \mathrm{LPVs}$ have been associated with an increased risk of prostate cancer [50], pancreatic cancer [47,51], and uveal melanoma [52,53].

According to the National Comprehensive Cancer Network (NCCN) guidelines, women with BRCA1/2 PV/LPVs should undergo a surveillance protocol, including clinical breast examination every 6-12 months and annual breast magnetic resonance imaging (MRI), starting at the age of 25, annual mammography with consideration of tomosynthesis, starting at the age of 30, and annual transvaginal ultrasound and serum CA-125 concentration, although of uncertain benefit, beginning at age 30-35 years [54]. Moreover, they should evaluate the opportunity of a bilateral risk-reducing mastectomy (RRM) and of a bilateral risk-reducing salpingo-oophorectomy (RRSO), typically at between 35 and 40 years and upon completion of childbearing [54]. Men with BRCA1/2 PV/LPVs should undergo clinical breast examination every 6-12 months, starting at the age of 35 , and annual prostate cancer screening, starting at the age of 40 (in particular in BRCA2 PV/LPV carriers) [55]. In both sexes, screening for melanoma and pancreatic cancer should be evaluated on the basis of family history [54]. Regarding the therapeutic approach, patients with germline BRCA1/2 variants can benefit from treatment with inhibitors of the poly adenosine-diphosphate ribose polymerase (PARP), that acts through the mechanism of synthetic lethality [56]. Moreover, somatic BRCA1/2 alterations are present in many sporadic cancers, in particular BCs and OCs, and even these tumors can be treated with PARP inhibitors, having the same molecular characteristics of hereditary cancers [57].

\subsection{TP53}

The TP53 gene is located on chromosome 17p13.1 and encodes the p53 protein, a tumor suppressor that responds to different cellular stresses to regulate expression of target genes, thereby inducing cell cycle arrest, apoptosis, senescence, DNA repair, or metabolism changes [58]. Due to its crucial function in maintaining the genomic stability, p53 has been defined "the guardian of the genome" and, indeed, somatic alterations of TP53 gene are present in about $50 \%$ of sporadic tumors [59], conferring to 553 an important role as a biomarker for the diagnosis, tumor progression, poor prognosis, and reduced sensitivity for anticancer drugs [60]. Moreover, p53 is a potential target for therapies because the restoration of its activity has shown to lead to tumor regression [61].

Germline PV/LPVs in the TP53 gene are associated with Li-Fraumeni syndrome (LFS), a rare autosomal dominant disorder characterized by a high predisposition to several types of cancer, such as brain tumors, sarcomas, acute leukemia, and adrenocortical tumors [25,62-69]. The lifetime risk of BC for patients with LFS is estimated to be $25-79 \%$ [70-72]. Patients with LFS also have an increased risk of developing genitourinary cancers, including OC, but this risk has not been estimated precisely [17,73]. Given the high risk of developing BC, the NCCN guidelines suggest that women with TP53 PV/LPVs should undergo clinical breast examination every 6-12 months starting at the age of 20, annual breast MRI screening with contrast from 20 to 75 years, and mammography with consideration of tomosynthesis from 30 to 75 years. After 75 years, the BC risk management should be considered on an individual basis [54]. Moreover, for women with a germline TP53 PV/LPV, RRM is an option that should be discussed [54].

\subsection{PTEN}

The PTEN gene is located on chromosome 10q23.31 and encodes a phosphatidylinositol-3,4,5trisphosphate 3-phosphatase, which antagonizes the PI3K signaling pathway through its lipid 
phosphatase activity and negatively regulates the MAPK (mitogen-activated protein kinase) pathway through its protein phosphatase activity [74]. PTEN is one of the most frequently disrupted tumor suppressors in cancer and, for this reason, therapeutic strategies aimed at tumors with loss of PTEN function are under evaluation [75].

Germline PV/LPVs in the PTEN gene are associated with the Cowden syndrome (CS), an autosomal dominant disorder characterized by benign hamartomas as well as by an increased lifetime risk of breast, thyroid, uterine, and other cancers [24,76]. The lifetime risk of BC in PTEN PV/LPV carriers is estimated to be $25-85 \%$, while the risk of OC is low or none [77-83]. In accordance with the NCCN guidelines, women with PTEN PV/LPVs should undergo clinical breast examination every 6-12 months starting at the age of 25 (or 5-10 years before the earliest known BC in the family), annual mammography with consideration of tomosynthesis and breast MRI screening with contrast starting at the age of 30-35 (or 5-10 years before the earliest known BC in the family). After 75 years, management should be considered on an individual basis. Moreover, for women with a germline PTEN PV/LPV, RRM is an option that should be taken into consideration [54].

Recently, germline PV/LPVs in PIK3CA and AKT1 genes have also been reported as being associated with CS [84], but the role of these genes in the pathogenesis of the disease is not well established.

\subsection{STK11}

The STK11 gene (formerly LKB1) is located on chromosome 19p13.3 and encodes a serine/threonine kinase that regulates energy metabolism and cell polarity [85]. The STK11 gene is a tumor suppressor that is mutated in a variety of sporadic cancers and, for this reason, different therapeutic strategies are under evaluation for the treatment of these tumors [86].

Germline PV/LPVs in the STK11 gene are associated with the Peutz-Jeghers syndrome [23], an autosomal dominant disorder characterized by melanocytic macules of the lips, buccal mucosa and digits, multiple gastrointestinal hamartomatous polyps, and an increased risk of different tumors. In STK11 PV/LPV carriers, the lifetime BC risk is estimated to be $32-54 \%$, and the risk of gynecological cancers (cervical, ovarian, uterine) is $13 \%$ by the age of $60[87,88]$. The NCCN guidelines suggest that women with STK11 PV/LPVs should undergo clinical breast examination every 6 months and annual mammography and breast MRI starting at the age of 25 [89]. For the risk of OC, they should undergo pelvic examination and Pap test annually starting at 18-20 years-old [89].

\section{5. $\mathrm{CDH1}$}

The CDH1 gene is located on chromosome 16q22.1 and encodes the E-cadherin, a transmembrane calcium-dependent protein involved in cell-cell adhesion [90], acting as a tumor suppressor [91] that prevents invasiveness and metastatization [92-94].

Germline PV/LPVs in the CDH1 gene are associated with Hereditary Diffuse Gastric Cancer syndrome (HDGC) [26], an autosomal dominant condition predisposing to diffuse-type gastric cancer (DGC) and lobular breast cancer (LBC). The cumulative risk of LBC for women with a CDH1 germline PV/LPV is estimated to be $39-52 \%$ by 80 years of age [27,95-97]. Given the high risk of developing LBC, according to the NCCN guidelines, women with a CDH1 PV/LPV should undergo annual mammography with consideration of tomosynthesis and breast MRI with contrast starting at the age of 30 [54]. However, there are insufficient data about RRM in these patients; consequently, it is an option that should be evaluated based on family history [54]. At the moment, there are no targeted therapies available for CDH1 PV/LPV carriers, but drug sensitivities derived from in vitro models of HDGC are under evaluation [98]. Moreover, somatic genetic and epigenetic alterations of the CDH1 gene occur frequently in sporadic tumors, such as gastric cancer and BC [99], and are associated with poor survival [100]. In particular, recent findings suggest that $C D H 1$ hypermethylation is a potential novel drug target for developing personalized therapy [101]. 


\section{Moderate and Low Penetrance Genes}

\subsection{PALB2, BRIP1, and other Fanconi Anemia Genes}

Fanconi anemia (FA) is a genetic disorder, characterized by multiple congenital abnormalities, bone marrow failure, and susceptibility to cancer [34]. The syndrome is caused by biallelic PV/LPVs in one of the 22 FA and FA-like genes that have been identified (except for FANCB, which is dominant, being located on the $\mathrm{X}$ chromosome) [102]. BRCA1 and BRCA2 genes (formerly FANCS and FANCD1, respectively) are also included in this group, even if the involvement of BRCA1 in FA has been debated [103] because its biallelic PV/LPVs have been suggested to be lethal during embryonic development $[104,105]$. However, there are multiple reports of FA patients with BRCA1 biallelic PV/LPVs, probably due to the retention of a partial activity by the protein [106-110]. Proteins encoded by the FA genes act as tumor suppressors, creating a complex that is activated in case of DNA damage and recruits other proteins involved in DNA repair via HR [111].

Monoallelic PV/LPVs of many FA genes have been reported as being associated with a BC/OC risk, such as FANCC, FANCM, and some RAD51 paralogs (see also paragraph 3.5.) [14,112-120], but the ones clearly involved in cancer predisposition are PALB2 and BRIP1. Although further studies are required, all these observations suggest that monoallelic PV/LPVs in FA genes are likely to increase the risk of BC/OC [121].

The PALB2 gene is located on chromosome 16p12.2 and encodes a protein that colocalizes with BRCA2 in nuclear foci, promotes its localization and stability in nuclear structures, and enables its recombinational repair and checkpoint functions [48]. PALB2 binds the single-strand DNA and directly interacts with the recombinase RAD51 to stimulate strand invasion during the HR process [49]. Biallelic PV/LPVs in the PALB2 gene (formerly FANCN) are associated with FA. However, monoallelic PV/LPVs in the PALB2 gene lead to a higher risk of BC for both sexes [122-126], which has been recently estimated at $53 \%$ for females and at $1 \%$ for males by the age of 80 [33]. In patients with PALB2 PV/LPVs, there is also a low increase in the risk of OC [127] and of pancreatic cancer [128,129], which has been estimated at $5 \%$ and $2-3 \%$, respectively, by the age of 80 [33]. The NCCN guidelines suggest that women with PALB2 PV/LPVs should undergo annual mammography with consideration of tomosynthesis and breast MRI starting at the age of 30 [54]. Moreover, RRM is an option that should be considered, whereas data about RRSO are insufficient, and family history should be taken into account [54].

The BRIP1 gene is located on chromosome 17q23.2 and encodes a DNA helicase that binds directly to the BRCT repeats of BRCA1 and is necessary for efficient DSB repair in the HR process [130,131]. Biallelic PV/LPVs in the BRIP1 gene (formerly FANCJ) are also associated with FA. However, monoallelic PV/LPVs in the BRIP1 gene lead to a higher risk of OC that is estimated to be around $6 \%$ during a lifetime [127,132]. In contrast to the PALB2 gene, the risk of BC for BRIP1 PV/LPV carriers is estimated to be low or none [133-135], and there is insufficient evidence for risk management [54]. For the risk of OC, according to the NCCN guidelines, RRSO is an option that should be evaluated at 45-50 years or earlier based on family history [54].

Given the involvement of the FA complex in the HR process, some clinical trials are evaluating the efficacy of PARP inhibitors in patients with metastatic BC and germline alterations of PALB2, BRIP1, and other FA genes such as FANCA, FANCC, FANCD2, FANCE, FANCF, and FANCM [136]. Moreover, germline and somatic alterations in genes involved in $\mathrm{HR}$ can predict platinum response and survival in ovarian, fallopian tube, and peritoneal carcinomas [137], giving new therapeutic opportunities for these tumors.

\subsection{ATM}

The ATM gene is located on chromosome 11q22.3 and encodes a phosphatidylinositol 3-kinase protein that acts as a tumor suppressor and responds to DNA damage by phosphorylating key substrates involved in DNA repair and cell cycle control [138]. 
Biallelic PV/LPVs in the ATM gene are associated with ataxia-telangiectasia [28], an autosomal recessive disorder characterized by cerebellar ataxia, telangiectases, immune defects, and a predisposition to malignancy $[28,139]$. However, monoallelic PV/LPVs are associated with an increased risk of BC that is estimated to be $17-52 \%$ during a lifetime [140-145]. The NCCN guidelines suggest that women with an ATM PV/LPV should undergo annual mammography with consideration of tomosynthesis and breast MRI with contrast starting at the age of 40 [54]. There is insufficient evidence about RRM in these patients and this option should be evaluated based on family history [54]. Moreover, given the involvement of ATM in the DNA repair processes, there are clinical trials that are evaluating the efficacy of PARP inhibitors in patients with ATM germline variants and metastatic $\mathrm{BC}$ [136]. In addition to germline variants, somatic ATM alterations commonly occur in a number of sporadic human cancers, in particular leukemias and carcinomas of the breast and lung [146], and these findings generate new opportunities for the future treatment of these tumors.

\subsection{CHEK2}

The CHEK2 gene is located on chromosome 22q12.1 and encodes a nuclear Ser/Thr kinase that acts as a tumor suppressor in different cellular processes [147]. In response to DSBs, CHEK2 protein is phosphorylated by ATM and catalyzes the phosphorylation of CDC25C, down-regulating it and preventing entry into mitosis [148]. Furthermore, after DNA damage, CHEK2 phosphorylates the p53 tumor suppressor protein and prevents its degradation, leading to cell cycle arrest in G1 [149]. Under gamma irradiation, CHEK2 also phosphorylates BRCA1 on Ser-988, activating the DNA repair process [150]. Finally, CHEK2 has been shown to induce apoptosis independently from p53, via phosphorylation of the PML (promyelocytic leukemia protein) tumor suppressor [151].

The first CHEK2 germline PV/LPVs identified have been associated with the Li-Fraumeni syndrome [152,153]; subsequently, this association has been questioned because of phenotype differences among LFS patients and CHEK2 PV/LPV carriers [154]. Germline PV/LPVs in this gene are associated with an increased risk of BC [155-158], which is estimated to be 25-39\% during a lifetime $[29,159,160]$. In particular, CHEK2 variant c.1100delC is associated with a two- to three-fold increase in BC risk in women and a ten-fold increase of risk in men [161-163]. In accordance with the NCCN guidelines, women with a CHEK2 PV/LPV should undergo annual mammography with consideration of tomosynthesis and breast MRI with contrast starting at the age of 40 [54]. However, there is insufficient evidence about RRM in these patients, and family history should be considered [66]. In addition to BC, CHEK2 PV/LPVs have also been associated with other cancers [164], including prostate [165-167], colorectal [168], and gastric cancers [169]. PV/LPVs in the CHEK2 gene have also been linked to OC risk [17,170], but this association has been debated for a long time [73,171-174], and there are insufficient data to recommend a surveillance protocol or RRSO [54]. Moreover, given the involvement of CHEK2 in DNA repair processes, there are clinical trials that are evaluating the efficacy of PARP inhibitors in patients with CHEK2 germline variants and metastatic BC [136]. In addition to germline variants, somatic CHEK2 alterations commonly occur in sporadic cancers [175], and these findings pave the way for the development of new targeted therapies.

\subsection{BARD1}

The BARD1 gene is located on chromosome $2 \mathrm{q} 35$ and encodes a protein that interacts with the N-terminal region of BRCA1 [176] and acts as a tumor suppressor creating a BRCA1/BARD1 heterodimer with ubiquitin E3 ligase activity [177].

PV/LPVs in the BARD1 gene have been associated with an approximately two-fold increase of lifetime $B C$ risk [12,178-182], but the penetrance has not been estimated precisely and a surveillance protocol is not routinely recommended [54]. Moreover, BARD1 PV/LPVs have also been linked to OC risk $[17,179]$, but this association has been recently excluded $[30,127]$. Given the involvement of BARD1 in the HR process and its association with the BRCA1 protein, there are clinical trials that are evaluating the efficacy of PARP inhibitors in patients with germline BARD1 variants and metastatic BC [136]. 
Moreover, somatic alterations of the BARD1 gene have been identified in different tumors, such as BC and uterine cancer [183], generating new opportunities for the future treatment of these tumors.

\subsection{RAD51C, RAD51D, and other RAD51 Paralogs}

The RAD51 gene encodes a protein involved in the repair of DSBs during the HR process. In mammals, seven $R A D 51$ paralogs have been identified: RAD51, RAD51B, RAD51C, RAD51D, $X R C C 2, X R C C 3$, and DMC1 [184]. The paralogs form two identified complexes: BCDX2 (RAD51B-RAD51C-RAD51D-XRCC2) and CX3 (RAD51C-XRCC3), which act in different stages of HR: The BCDX2 complex is responsible for the recruitment or stabilization of RAD51 at damage sites and the CX3 complex acts downstream of this process [185].

Biallelic PV/LPVs of the RAD51, RAD51C, and XRCC2 genes (formerly FANCR, FANCO, and FANCU, respectively) are associated with FA (see paragraph 3.1.) [34]. In contrast to this, monoallelic variants of the RAD51 gene and of five of its paralogs have recently been involved in cancer predisposition: $R A D 51 B, R A D 51 C$, and RAD51D in OC; RAD51, RAD51B, and XRCC2 in $\mathrm{BC}[35,186-194]$. However, the two genes well known to be associated with cancer risk are $R A D 51 C$ and RAD51D [36,37,195].

The RAD51C gene is located on chromosome 17q22 and encodes a protein that acts in HR creating complexes with other RAD51 paralogs [185]. The lifetime risk of OC for RAD51C PV/LPV carriers is estimated to be around $7 \%$, whereas the $B C$ risk is controversial $[35,36]$.

The RAD51D gene is located on chromosome $17 \mathrm{q} 12$ and encodes a protein that, as well as RAD51C, interacts with other RAD51 paralogs in the process of HR [196]. The lifetime risk of OC for RAD51D $\mathrm{PV} / \mathrm{LPV}$ carriers is estimated to be around $15 \%$, whereas the BC risk is controversial $[35,37]$.

The lifetime risk of OC in carriers of PV/LPVs of the RAD51C and RAD51D genes appears to be sufficient to justify consideration of RRSO, which, according to NCCN guidelines, should be held around the age of 45-50, or earlier based on family history [54]. Germline and somatic alterations in HR genes predict platinum response and survival in ovarian, fallopian tube, and peritoneal carcinomas [137], and there are clinical trials that are evaluating the efficacy of PARP inhibitors in patients with germline $R A D 51 C / D$ variants and metastatic BC [136].

\subsection{MRN Complex}

The MRN complex (MRE11-RAD50-NBS1) is a complex of three proteins (encoded by MRE11, $R A D 50$, and NBN genes) involved in the repair of DSBs and in telomere maintenance [197]. These proteins are known tumor suppressors because loss of function of any of them results in genome instability, and defective MRN function has been linked to many types of cancer, including breast, ovarian, colorectal, gastric, and prostate cancers, as well as leukemia and melanoma [197]. Germline variants in these three genes have also been associated with an increased risk of BC/OC [137,198-201]; in particular, the NBN gene, located on chromosome 8q21.3, which encodes the Nibrin protein, also known as p95 and NBS1 [202], which is responsible for the localization of the complex and for the interactions with other DSB-signaling and DNA-repair proteins [197].

Biallelic PV/LPVs of NBN are the cause of Nijmegen breakage syndrome (NBS), an autosomal recessive disease characterized by chromosomal instability that determines progressive microcephaly, intrauterine growth retardation and short stature, recurrent sinopulmonary infections, an increased risk for cancer, and premature ovarian failure in females [32]. RAD50 and MRE11 biallelic PV/LPVs have also been associated with an NBS-like disorder [203,204].

On the other hand, NBN monoallelic PV/LPVs predispose to the development of BC, prostate cancer, medulloblastoma, and melanoma [205-211]. In particular, women with the 657del5 variant have a higher risk of $\mathrm{BC}$, and NCCN guidelines suggest that they should undergo annual mammography with consideration of tomosynthesis and breast MRI with contrast starting at the age of 40 . Of note, current data suggest that $\mathrm{BC}$ risk is not increased for carriers of PV/LPVs other than 657del5 [54]. NBN germline PV/LPVs have also been identified in patients with OC, but the link between NBN alterations 
and OC risk is still under evaluation $[17,127,137,212]$, and there are insufficient data to recommend a surveillance protocol or RRSO [54]. Moreover, given the involvement of the MRN complex in the HR, there are clinical trials that are evaluating the efficacy of PARP inhibitors in patients with NBN, MRE11, and RAD50 variants and metastatic BC [136].

Variants in RINT1 gene have also been associated with BC risk [213]. This gene encodes a protein that was first identified for its ability to interact with the RAD50 protein in the regulation of cell cycle progression and telomere length [214]. This association is intriguing given the RINT1 protein function, but it needs to be investigated further.

\subsection{Mismatch Repair Genes}

Lynch syndrome (LS) is an autosomal dominant disorder, characterized by a high risk of developing colorectal and endometrial cancers [38]. LS is caused by PVs in the MLH1, MSH2, MSH6, and PMS2 genes, coding the proteins of the DNA mismatch repair (MMR) [215], or by large deletions of the EPCAM gene, located upstream of the MSH2 gene [216]. MMR proteins work coordinately in sequential steps to initiate repair of DNA mismatches, constituted by erroneous insertions, deletions, and substitutions of bases that can arise during DNA replication and recombination [217].

Patients with LS also have an increased risk of developing other tumors, in particular, they have a lifetime risk of OC that is estimated to be $4-12 \%[218,219]$. Unlike OCs associated with PV/LPVs in $B R C A 1 / 2$ genes, which are mainly of the serous type, those associated with LS are more likely to be endometrioid or clear cell [220]. Whether LS is directly related to BC predisposition is currently a matter of debate [115,218,221-224]: PVs of the MMR genes have been reported in patients with BC [117,225], but a consistent association between LS and BC has never been demonstrated [226-228].

Regarding surveillance for LS patients, the data do not support routine OC screening (transvaginal ultrasound and serum CA-125 testing may be considered but have not been shown to be sufficiently sensitive or specific to warrant a routine recommendation). In accordance with the NCCN guidelines, bilateral RRSO is an option that may be considered and individualized based on whether childbearing is complete, menopausal status, comorbidities, family history, and LS gene, as risks for OC vary by the mutated gene (there is insufficient evidence to recommend RRSO in MSH6 and PMS2 PV/LPV carriers) [89]. Given the uncertain risk of BC in LS patients, breast surveillance is not recommended but should be evaluated based on family history [89].

Moreover, patients with LS, who have a deficiency of the MMR system (dMMR), can benefit from chemoprevention based on the use of daily aspirin [229] and can be treated with anti-PD-1/PD-L1 therapy [230,231]. The dMMR also arises in sporadic cancers through genetic or epigenetic mechanisms [232] and is observed in a reasonable proportion of OCs [233], generating important implications on the treatment and prognosis [234].

\subsection{NF1}

The NF1 gene is located on chromosome 17q11.2 and encodes Neurofibromin, a cytoplasmic protein that regulates several intracellular processes, including the Ras-cAMP (cyclic adenosine monophosphate) pathway, the ERK (extracellular signal-regulated kinase)/MAPK cascade, adenylyl cyclase, and cytoskeletal assembly [235]. In particular, Neurofibromin has been shown to increase the rate of guanosine triphosphate (GTP) hydrolysis of Ras and act as a tumor suppressor by reducing Ras activity [236,237].

Germline PV/LPVs in the NF1 gene are responsible for Neurofibromatosis type I, an autosomal dominant syndrome characterized by multiple café au lait spots, axillary and inguinal freckling, multiple cutaneous neurofibromas, iris Lisch nodules, and choroidal freckling [31].

Women with NF1 PV/LPVs have a substantially increased risk of developing BC before the age of 50 [14,238-241] and of dying of BC [242]. In these patients, according to the NCCN guidelines, mammography with consideration of tomosynthesis should be performed annually beginning at the 
age of 30, and annual breast MRI with contrast should be considered between the ages of 30 and 50 [54]. However, the efficacy and cost-effectiveness of such surveillance have not yet been demonstrated [243].

In addition to germline variants, somatic NF1 alterations commonly occur in sporadic cancers and are associated with increased cancer risk and drug resistance [244]. This generates implications even on the treatment of these tumors because, in NF1-deficient tumors, some drugs, such as MEK inhibitors, have shown their efficacy [245].

\section{Other Emerging Genes}

Thanks to the wide use of NGS, the number of genes that have been associated with a BC/OC risk has hugely increased in the last few years. However, the most critical issue is the penetrance estimate of the penetrance of these PV/LPVs.

Recently, PV/LPVs in genes coding RecQ helicases have been reported in patients with BC/OC [117,246-254]. Interestingly, PV/LPVs in three of these genes are responsible for autosomal recessive genetic syndromes, all associated with an increased risk of malignancies: In fact, BLM, WRN, and RECL4 genes are the genetic cause of Bloom syndrome [255], Werner syndrome [256], and Rothmund-Thomson syndrome [257], respectively.

The proteins encoded by the ABRAXAS1 and UIMC1 genes (also known as FAM175A and RAP80) form a complex with BRCA1, required for DNA damage response [258]. PV/LPVs in both genes have been linked to an increased risk of BC, but penetrance estimates are still missing $[259,260]$.

Other genes, such as PPM1D, ERCC3, BAP1, and NTHL1 have been reported in BC/OC families [117,261-266], but further studies are needed to confirm these associations.

Moreover, in 2018, a systematic review of The Cancer Genome Atlas (TCGA) data was performed, focusing on pathogenic germline variants: besides the BRCA1 and BRCA2 genes, PV/LPVs in ATM, PALB2, RET, NF1, TP53, BUB1B, MAX, and APC genes have been detected in BC patients, and PV/LPVs in ATM, PALB2, TP53, NF1, and SDHA genes have been detected in OC patients [267]. Some of these genes are intriguing candidates in the predisposition to $\mathrm{BC} / \mathrm{OC}$ and, in the future, could be included in diagnostic panels for the assessment of cancer risk.

\section{Conclusions}

$\mathrm{BC}$ and $\mathrm{OC}$ are both in the top 10 of the most common and deadly tumors for women and, among risk factors for the development of these cancers, genetic predisposition plays an important role.

$B R C A 1$ and $B R C A 2$ have been known for decades to be predisposition genes to $\mathrm{BC}$ and $\mathrm{OC}$. Consequently, for PV/LPV carriers in these genes, accurate cancer risk estimates are available, as well as surveillance protocols for cancer prevention and early detection of the disease.

New genes are constantly emerging from NGS studies $[10,14,16,117,180,268-272]$, showing that $\mathrm{BC} / \mathrm{OC}$ predisposition is distributed over many genes, with only a few genes being recurrently mutated. However, testing on genes other than $B R C A 1$ and $B R C A 2$ is not routinely performed, due to lack of information about the actual risks for PV/LPV carriers and the unavailability of surveillance programs.

Besides BRCA1 and BRCA2, there are some genes with high penetrance, such as TP53, PTEN, STK11, and CDH1, whose variants are associated with other cancer genetic syndromes (Table 1) that, however, also include a high risk of BC and/or OC. Consequently, these genes need to be included in a panel of genes for the identification of patients at risk of BC/OC. Moreover, there are some other genes, such as PALB2, BRIP1, ATM, CHEK2, BARD1, RAD51C, RAD51D, NBN, NF1, and MMR genes that are classified as moderate or low penetrance genes for the risk of $B C / O C$ (Table 1), but the increasing evidence of associated cancer risks and the availability of recommendations for the management of the variant carriers suggest that they should be included, whenever possible, in a gene panel for $\mathrm{BC} / \mathrm{OC}$ predisposition.

In particular, $P A L B 2$ is emerging as the most important $B C$ predisposition gene after $B R C A 1$ and $B R C A 2[122,123]$, but at the same time, it is still classified as a moderate penetrance gene. In the last few years, many studies pinpointed this gene as being associated with a high risk of $B C$ and a high 
rate of bilateral $\mathrm{BC}$ [117]. These observations further highlight both the high risk of $\mathrm{BC}$ associated with PALB2 PVs and the importance of adding the PALB2 gene to standard genetic tests for patients with suspected HBOC syndrome.

NGS-based approaches have also highlighted unexpected overlapping among genetic syndromes predisposing to $\mathrm{BC} / \mathrm{OC}$ and gastrointestinal tumors, such as colorectal, gastric, and pancreatic cancers, raising the question of phenotypes associated with individual cancer susceptibility genes [273,274]. These findings address the choice of wide panels, including the genes involved in the main cancer syndromes that can be used independently of the personal and family history of cancer. This creates new diagnostic opportunities but also increases the risk of an incorrect genetic diagnosis [275].

On the whole, it is indisputable that NGS has deeply increased our knowledge of BC predisposition by increasing the number of susceptibility genes. However, because of the growing demand for higher throughput and lower costs, quality data and standardized procedures need to be carefully assessed. Moreover, genetic counseling and risk evaluation, as well as clinical management of patients and families at risk, are becoming more and more challenging [276]. In particular, all health-care professionals who offer genetic testing must engage in constant education as the field is continuously evolving, with new data becoming available [277]. An important aspect is the selection of patients for the genetic test, which is currently based on the number and type of cancers in the family and on the age of onset of these tumors. Several models are available to estimate the probability of having a BRCA1/2 variant [278-284]. These models can be used to select patients for a multigene panel test for the risk of $\mathrm{BC} / \mathrm{OC}$ but, with the increase in the number of predisposing genes, they should be improved to identify individuals who can really benefit from a genetic test and, at the same time, to avoid the overuse of genetic tests.

Moreover, another important issue for patients with a cancer predisposition syndrome is prophylactic surgery. To date, we know that prophylactic surgery is an option that should be evaluated by patients with specific syndromes. In women with BRCA1/2 PV/LPVs, bilateral RRM and bilateral RRSO have been demonstrated as effective measures to prevent cancer [285]. In individuals with LS, prophylactic hysterectomy and bilateral RRSO can be considered after childbearing is completed, whereas prophylactic colectomy before the development of colon cancer is generally not recommended because screening colonoscopy with polypectomy is an effective preventive measure [286]. Finally, for individuals with CDH1 PV/LPVs, prophylactic gastrectomy should be strongly advised; however, there are insufficient data about prophylactic mastectomy [287]. For individuals with PV/LPVs in other cancer genes, more data are needed to perform a risk-benefit assessment of prophylactic surgeries but, for some genes, guidelines suggest that RRM and/or RRSO should be evaluated in accordance with family history and, in particular, the age of onset of the tumors in the family $[54,89]$.

Recently, cancer genetic predisposition and precision medicine have found a contact point, thanks to the discovery of the therapeutic potential of PARP inhibitors in BRCA1/2 PV/LPV carriers [288,289], at first in OC [290] and then in BC, prostate, and pancreatic cancers [291-293]. PARP inhibitors have shown their efficacy, not only in patients with germline and somatic BRCA1/2 alterations [57], but also in patients with PV/LPVs in genes involved in the HR pathway with BRCA1 and BRCA2 proteins [294-297], and clinical trials are currently addressing this [136]. These results pave the way for the future use of PARP inhibitors in all tumors with a deficiency of the HR system, independently of the germline or somatic nature of the alteration.

These "personalized" treatments are possible thanks to the fact that tumors originating in individuals with a germline PV/LPV in a cancer predisposition gene usually have a specific "mutational signature" that reflects the pathway in which the gene is involved [298]. Indeed, the main genes associated with $\mathrm{BC} / \mathrm{OC}$ predisposition encode proteins that act as tumor suppressors being involved mostly in DNA damage repair processes, such as HR and MMR, and are strictly linked together. This aspect will become very important in the future because it can help in the identification of new genes involved in the predisposition and can guide the choice of the best therapeutic approach in terms of 
targeted therapies, chemoprevention, and prophylactic surgeries for a medicine personalized on the genetic characteristics of the patient.

The diagnostic use of multigene panels, instead of the traditional single-gene analysis, generates many advantages as well as some critical issues. Before the advent of NGS, turn-around times for genetic testing were long, in some cases more than 6-12 months, while nowadays new technologies provide results in less than a month in many cases. This short time is extremely useful for the affected individuals because the result of the genetic test can address or modify the surgical and therapeutic approach to the disease but, at the same time, it can generate issues in the genetic counseling and the management of the family, since the implications of cancer predisposition need time to be understood properly by the patient and by family members. The use of large gene panels can also create an increase in the number of false-positive findings [299]. For this reason, a second confirmatory analysis is always recommended, possibly with another technique, such as Sanger sequencing [300]. Another important issue is the interpretation of variants of uncertain significance (VUS), whose number increases exponentially with the increase of tested genes. Of note, the assessment of the pathogenicity of the genetic variants is based on guidelines that take into account many factors [301], but this classification refers to the potential role in cancer development without taking into account the penetrance and the spectrum of the associated diseases. Many non-easily classifiable variants are identified by NGS studies and, although several techniques can now be used to investigate their pathogenicity [302], efficient and accurate classification methods are still needed to translate theoretical information into clinical practice. The bioinformatics tools for the prediction of pathogenicity seem inadequate to classify many variants and to identify higher-risk patients [117]. However, risk assessment of candidate variants is made difficult by the limited number of variant carriers and by the possible interference of different genetic and environmental factors. The multifactorial nature of $\mathrm{BC} / \mathrm{OC}$ and the presence of predisposing variants in genes never included in panels for standard genetic tests are likely to further increase the complexity of the scenario.

Taking into account all these considerations, it is clear how difficult it is to find the right combination of genes to be tested in patients with a suspected genetic predisposition to $\mathrm{BC} / \mathrm{OC}$. At the international level, efforts are being made to achieve a consensus [303-306], but the identification of a balance between costs for health systems and benefits for patients remains one of the biggest challenges for the future. Moreover, larger case-control studies are needed to better refine the penetrance estimates and to evaluate the correct preventive and therapeutic approach for each patient.

Conflicts of Interest: The authors declare no conflict of interest.

\section{Abbreviations}

$\begin{array}{ll}\text { AD } & \text { Autosomal dominant } \\ \text { AR } & \text { Autosomal recessive } \\ \text { BASC } & \text { BRCA1-associated genome surveillance complex } \\ \text { BC } & \text { Breast cancer } \\ \text { cAMP } & \text { Cyclic adenosine monophosphate } \\ \text { DGC } & \text { Diffuse-type gastric cancer } \\ \text { DSB } & \text { Double-strand break } \\ \text { ERK } & \text { Extracellular signal-regulated kinase } \\ \text { FA } & \text { Fanconi anemia } \\ \text { GTP } & \text { Guanosine triphosphate } \\ \text { HBOC } & \text { Hereditary Breast and Ovarian Cancer } \\ \text { HDGC } & \text { Hereditary Diffuse Gastric Cancer syndrome } \\ \text { HR } & \text { Homologous recombination } \\ \text { LBC } & \text { Lobular breast cancer } \\ \text { LFS } & \text { Li-Fraumeni syndrome } \\ \text { LPV } & \text { Likely-pathogenic variant } \\ \text { LS } & \text { Lynch syndrome }\end{array}$




$\begin{array}{ll}\text { MAPK } & \text { Mitogen-activated protein kinase } \\ \text { MBC } & \text { Male breast cancer } \\ \text { MMR } & \text { Mismatch repair } \\ \text { MRI } & \text { Magnetic resonance imaging } \\ \text { MRN } & \text { MRE11-RAD50-NBS1 complex } \\ \text { NA } & \text { Not assessed } \\ \text { NBS } & \text { Nijmegen breakage syndrome } \\ \text { NCCN } & \text { National Comprehensive Cancer Network } \\ \text { NGS } & \text { Next-Generation Sequencing } \\ \text { OC } & \text { Ovarian cancer } \\ \text { PARP } & \text { Poly adenosine-diphosphate ribose polymerase } \\ \text { PJS } & \text { Peutz-Jeghers syndrome } \\ \text { PML } & \text { Promyelocytic leukemia protein } \\ \text { PV } & \text { Pathogenic variant } \\ \text { RR } & \text { Relative risk } \\ \text { RRM } & \text { Risk-reducing mastectomy } \\ \text { RRSO } & \text { Risk-reducing salpingo-oophorectomy } \\ \text { TCGA } & \text { The Cancer Genome Atlas } \\ \text { VUS } & \text { Variant of uncertain significance }\end{array}$

\section{References}

1. Bray, F.; Ferlay, J.; Soerjomataram, I.; Siegel, R.L.; Torre, L.A.; Jemal, A. Global cancer statistics 2018: GLOBOCAN estimates of incidence and mortality worldwide for 36 cancers in 185 countries. CA Cancer J. Clin. 2018, 68, 394-424. [CrossRef] [PubMed]

2. Ruddy, K.J.; Winer, E.P. Male breast cancer: Risk factors, biology, diagnosis, treatment, and survivorship. Ann. Oncol. 2013, 24, 1434-1443. [CrossRef] [PubMed]

3. Ottini, L. Male breast cancer: A rare disease that might uncover underlying pathways of breast cancer. Nat. Rev. Cancer 2014, 14, 643. [CrossRef]

4. Rizzolo, P.; Zelli, V.; Silvestri, V.; Valentini, V.; Zanna, I.; Bianchi, S.; Masala, G.; Spinelli, A.M.; Tibiletti, M.G.; Russo, A.; et al. Insight into genetic susceptibility to male breast cancer by multigene panel testing: Results from a multicenter study in Italy. Int. J. Cancer 2019, 145, 390-400. [CrossRef] [PubMed]

5. Gage, M.; Wattendorf, D.; Henry, L.R. Translational advances regarding hereditary breast cancer syndromes. J. Surg. Oncol. 2012, 105, 444-451. [CrossRef] [PubMed]

6. Prat, J.; Ribé, A.; Gallardo, A. Hereditary ovarian cancer. Hum. Pathol. 2005, 36, 861-870. [CrossRef]

7. Miki, Y.; Swensen, J.; Shattuck-Eidens, D.; Futreal, P.A.; Harshman, K.; Tavtigian, S.; Liu, Q.; Cochran, C.; Bennett, L.M.; Ding, W. A strong candidate for the breast and ovarian cancer susceptibility gene BRCA1. Science 1994, 266, 66-71. [CrossRef]

8. Wooster, R.; Bignell, G.; Lancaster, J.; Swift, S.; Seal, S.; Mangion, J.; Collins, N.; Gregory, S.; Gumbs, C.; Micklem, G. Identification of the breast cancer susceptibility gene BRCA2. Nature 1995, 378, 789-792. [CrossRef]

9. Petrucelli, N.; Daly, M.B.; Pal, T. BRCA1- and BRCA2-Associated Hereditary Breast and Ovarian Cancer. In GeneReviews; Adam, M.P., Ardinger, H.H., Pagon, R.A., Eds.; University of Washington: Seattle, WA, USA, 1998; [Updated 2016]. Available online: https://www.ncbi.nlm.nih.gov/books/NBK1247 (accessed on 7 February 2020).

10. Easton, D.F.; Pharoah, P.D.P.; Antoniou, A.C.; Tischkowitz, M.; Tavtigian, S.V.; Nathanson, K.L.; Devilee, P.; Meindl, A.; Couch, F.J; Southey, M.; et al. Gene-panel sequencing and the prediction of breast-cancer risk. N. Engl. J. Med. 2015, 372, 2243-2257. [CrossRef]

11. Kwong, A.; Chen, J.W.; Shin, V.Y. A new paradigm of genetic testing for hereditary breast/ovarian cancers. Hong Kong Med. J. 2016, 22, 171-177. [CrossRef]

12. Apostolou, P.; Fostira, F. Hereditary breast cancer: The era of new susceptibility genes. Biomed. Res. Int. 2013, 2013, 747318. [CrossRef] [PubMed] 
13. Norquist, B.M.; Harrell, M.I.; Brady, M.F.; Walsh, T.; Lee, M.K.; Gulsuner, S.; Bernards, S.S.; Casadei, S.; Yi, Q.; Burger, R.A.; et al. Inherited Mutations in Women With Ovarian Carcinoma. JAMA Oncol. 2016, 2, 482-490. [CrossRef] [PubMed]

14. Kurian, A.W.; Antoniou, A.C.; Domchek, S.M. Refining Breast Cancer Risk Stratification: Additional Genes, Additional Information. Am. Soc. Clin. Oncol. Educ. Book Am. Soc. Clin. Oncol. Annu. Meet. 2016, 35, 44-56. [CrossRef] [PubMed]

15. Hollestelle, A.; Wasielewski, M.; Martens, J.W.M.; Schutte, M. Discovering moderate-risk breast cancer susceptibility genes. Curr. Opin. Genet. Dev. 2010, 20, 268-276. [CrossRef]

16. Nielsen, F.C.; van Overeem Hansen, T.; Sørensen, C.S. Hereditary breast and ovarian cancer: New genes in confined pathways. Nat. Rev. Cancer 2016, 16, 599-612. [CrossRef] [PubMed]

17. Walsh, T.; Casadei, S.; Lee, M.K.; Pennil, C.C.; Nord, A.S.; Thornton, A.M.; Roeb, W.; Agnew, K.J.; Stray, S.M.; Wickramanayake, A.; et al. Mutations in 12 genes for inherited ovarian, fallopian tube, and peritoneal carcinoma identified by massively parallel sequencing. Proc. Natl. Acad. Sci. USA 2011, 108, 18032-18037. [CrossRef] [PubMed]

18. Di Resta, C.; Galbiati, S.; Carrera, P.; Ferrari, M. Next-generation sequencing approach for the diagnosis of human diseases: Open challenges and new opportunities. EJIFCC 2018, 29, 4-14.

19. Sud, A.; Kinnersley, B.; Houlston, R.S. Genome-wide association studies of cancer: Current insights and future perspectives. Nat. Rev. Cancer 2017, 17, 692-704. [CrossRef]

20. Antoniou, A.; Pharoah, P.D.P.; Narod, S.; Risch, H.A.; Eyfjord, J.E.; Hopper, J.L.; Loman, N.; Olsson, H.; Johannsson, O.; Borg, A.; et al. Average risks of breast and ovarian cancer associated with BRCA1 or BRCA2 mutations detected in case Series unselected for family history: A combined analysis of 22 studies. Am. J. Hum. Genet. 2003, 72, 1117-1130. [CrossRef]

21. Chen, S.; Parmigiani, G. Meta-analysis of BRCA1 and BRCA2 penetrance. J. Clin. Oncol. 2007, 25, 1329-1333. [CrossRef]

22. Mavaddat, N.; Peock, S.; Frost, D.; Ellis, S.; Platte, R.; Fineberg, E.; Evans, D.G.; Izatt, L.; Eeles, R.A.; Adlard, J.; et al. Cancer risks for BRCA1 and BRCA2 mutation carriers: Results from prospective analysis of EMBRACE. J. Natl. Cancer Inst. 2013, 105, 812-822. [CrossRef] [PubMed]

23. McGarrity, T.J.; Amos, C.I.; Baker, M.J. Peutz-Jeghers Syndrome. In GeneReviews; Adam, M.P., Ardinger, H.H., Pagon, R.A., Eds.; University of Washington: Seattle, WA, USA, 2001; [Updated 2016]. Available online: https://www.ncbi.nlm.nih.gov/books/NBK1266 (accessed on 7 February 2020).

24. Eng, C. PTEN Hamartoma Tumor Syndrome. In GeneReviews; Adam, M.P., Ardinger, H.H., Pagon, R.A., Eds.; University of Washington: Seattle, WA, USA, 2001; [Updated 2016]. Available online: https://www.ncbi.nlm. nih.gov/books/NBK1488 (accessed on 7 February 2020).

25. Schneider, K.; Zelley, K.; Nichols, K.E.; Garber, J. Li-Fraumeni Syndrome. In GeneReviews; Adam, M.P., Ardinger, H.H., Pagon, R.A., Eds.; University of Washington: Seattle, WA, USA, 1999; [Updated 2019]. Available online: https://www.ncbi.nlm.nih.gov/books/NBK1311 (accessed on 7 February 2020).

26. Kaurah, P.; Huntsman, D.G. Hereditary Diffuse Gastric Cancer. In GeneReviews; Adam, M.P., Ardinger, H.H., Pagon, R.A., Eds.; University of Washington: Seattle, WA, USA, 2002; [Updated 2018]. Available online: https://www.ncbi.nlm.nih.gov/books/NBK1139 (accessed on 7 February 2020).

27. Van der Post, R.S.; Vogelaar, I.P.; Carneiro, F.; Guilford, P.; Huntsman, D.; Hoogerbrugge, N.; Caldas, C.; Schreiber, K.E.C.; Hardwick, R.H.; Ausems, M.G.E.M.; et al. Hereditary diffuse gastric cancer: Updated clinical guidelines with an emphasis on germline CDH1 mutation carriers. J. Med. Genet. 2015, 52, 361-374. [CrossRef] [PubMed]

28. Gatti, R.; Perlman, S. Ataxia-Telangiectasia. In GeneReviews; Adam, M.P., Ardinger, H.H., Pagon, R.A., Eds.; University of Washington: Seattle, WA, USA, 1999; [Updated 2016]. Available online: https://www.ncbi.nlm. nih.gov/books/NBK26468 (accessed on 7 February 2020).

29. Cybulski, C.; Wokołorczyk, D.; Jakubowska, A.; Huzarski, T.; Byrski, T.; Gronwald, J.; Masojć, B.; Deebniak, T.; Górski, B.; Blecharz, P.; et al. Risk of breast cancer in women with a CHEK2 mutation with and without a family history of breast cancer. J. Clin. Oncol. 2011, 29, 3747-3752. [CrossRef] [PubMed]

30. Weber-Lassalle, N.; Borde, J.; Weber-Lassalle, K.; Horváth, J.; Niederacher, D.; Arnold, N.; Kaulfuß, S.; Ernst, C.; Paul, V.G.; Honisch, E.; et al. Germline loss-of-function variants in the BARD1 gene are associated with early-onset familial breast cancer but not ovarian cancer. Breast Cancer Res. 2019, 21, 55. [CrossRef] 
31. Friedman, J. Neurofibromatosis 1. In GeneReviews; Adam, M.P., Ardinger, H.H., Pagon, R.A., Eds.; University of Washington: Seattle, WA, USA, 1998; [Updated 2019]. Available online: https://www.ncbi.nlm.nih.gov/ books/NBK1109 (accessed on 7 February 2020).

32. Varon, R.; Demuth, I.; Chrzanowska, K.H. Nijmegen Breakage Syndrome. In GeneReviews; Adam, M.P., Ardinger, H.H., Pagon, R.A., Eds.; University of Washington: Seattle, WA, USA, 1999; [Updated 2017]. Available online: https://www.ncbi.nlm.nih.gov/books/NBK1176 (accessed on 7 February 2020).

33. Yang, X.; Leslie, G.; Doroszuk, A.; Schneider, S.; Allen, J.; Decker, B.; Dunning, A.M.; Redman, J.; Scarth, J.; Plaskocinska, I.; et al. Cancer Risks Associated with Germline PALB2 Pathogenic Variants: An International Study of 524 Families. J. Clin. Oncol. 2019. [CrossRef]

34. Mehta, P.A.; Tolar, J. Fanconi Anemia. Peutz-Jeghers Syndrome. In GeneReviews; Adam, M.P., Ardinger, H.H., Pagon, R.A., Eds.; University of Washington: Seattle, WA, USA, 2002; [Updated 2018]. Available online: https://www.ncbi.nlm.nih.gov/books/NBK1401 (accessed on 7 February 2020).

35. Song, H.; Dicks, E.; Ramus, S.J.; Tyrer, J.P.; Intermaggio, M.P.; Hayward, J.; Edlund, C.K.; Conti, D.; Harrington, P.; Fraser, L.; et al. Contribution of Germline Mutations in the RAD51B, RAD51C, and RAD51D Genes to Ovarian Cancer in the Population. J. Clin. Oncol. 2015, 33, 2901-2907. [CrossRef]

36. Loveday, C.; Turnbull, C.; Ruark, E.; Xicola, R.M.M.; Ramsay, E.; Hughes, D.; Warren-Perry, M.; Snape, K.; Eccles, D. Breast Cancer Susceptibility Collaboration (UK). Nat. Genet. 2012, 44, 475-476. [CrossRef]

37. Loveday, C.; Turnbull, C.; Ramsay, E.; Hughes, D.; Ruark, E.; Frankum, J.R.; Bowden, G.; Kalmyrzaev, B.; Warren-Perry, M.; Snape, K.; et al. Germline mutations in RAD51D confer susceptibility to ovarian cancer. Nat. Genet. 2011, 43, 879-882. [CrossRef]

38. Kohlmann, W.; Gruber, S.B. Lynch Syndrome. In GeneReviews; Adam, M.P., Ardinger, H.H., Pagon, R.A., Eds.; University of Washington: Seattle, WA, USA, 2004; [Updated 2018]. Available online: https://www.ncbi. nlm.nih.gov/books/NBK1211 (accessed on 7 February 2020).

39. Roy, R.; Chun, J.; Powell, S.N. BRCA1 and BRCA2: Different roles in a common pathway of genome protection. Nat. Rev. Cancer 2011, 12, 68-78. [CrossRef]

40. Foulkes, W.D.; Shuen, A.Y. In brief: BRCA1 and BRCA2. J. Pathol. 2013, 230, 347-349. [CrossRef]

41. Wang, Y.; Cortez, D.; Yazdi, P.; Neff, N.; Elledge, S.J.; Qin, J. BASC, a super complex of BRCA1-associated proteins involved in the recognition and repair of aberrant DNA structures. Genes Dev. 2000, 14, 927-939. [PubMed]

42. Hedenfalk, I.A.; Ringnér, M.; Trent, J.M.; Borg, A. Gene expression in inherited breast cancer. Adv. Cancer Res. 2002, 84, 1-34. [PubMed]

43. Tai, Y.C.; Domchek, S.; Parmigiani, G.; Chen, S. Breast cancer risk among male BRCA1 and BRCA2 mutation carriers. J. Natl. Cancer Inst. 2007, 99, 1811-1814. [CrossRef] [PubMed]

44. Ford, D.; Easton, D.F.; Bishop, D.T.; Narod, S.A.; Goldgar, D.E. Risks of cancer in BRCA1-mutation carriers. Breast Cancer Linkage Consortium. Lancet 1994, 343, 692-695. [CrossRef]

45. Leongamornlert, D.; Mahmud, N.; Tymrakiewicz, M.; Saunders, E.; Dadaev, T.; Castro, E.; Goh, C.; Govindasami, K.; Guy, M.; O’Brien, L.; et al. Germline BRCA1 mutations increase prostate cancer risk. Br. J. Cancer 2012, 106, 1697-1701. [CrossRef]

46. Thompson, D.; Easton, D.F. Breast Cancer Linkage Consortium Cancer Incidence in BRCA1 mutation carriers. J. Natl. Cancer Inst. 2002, 94, 1358-1365. [CrossRef]

47. Ghiorzo, P.; Pensotti, V.; Fornarini, G.; Sciallero, S.; Battistuzzi, L.; Belli, F.; Bonelli, L.; Borgonovo, G.; Bruno, W.; Gozza, A.; et al. Contribution of germline mutations in the BRCA and PALB2 genes to pancreatic cancer in Italy. Fam. Cancer 2012, 11, 41-47. [CrossRef]

48. Xia, B.; Sheng, Q.; Nakanishi, K.; Ohashi, A.; Wu, J.; Christ, N.; Liu, X.; Jasin, M.; Couch, F.J.; Livingston, D.M. Control of BRCA2 cellular and clinical functions by a nuclear partner, PALB2. Mol. Cell 2006, 22, 719-729. [CrossRef]

49. Buisson, R.; Dion-Côté, A.-M.; Coulombe, Y.; Launay, H.; Cai, H.; Stasiak, A.Z.A.; Stasiak, A.Z.A.; Xia, B.; Masson, J.-Y. Cooperation of breast cancer proteins PALB2 and piccolo BRCA2 in stimulating homologous recombination. Nat. Struct. Mol. Biol. 2010, 17, 1247-1254. [CrossRef]

50. Kote-Jarai, Z.; Leongamornlert, D.; Saunders, E.; Tymrakiewicz, M.; Castro, E.; Mahmud, N.; Guy, M.; Edwards, S.; O'Brien, L.; Sawyer, E.; et al. BRCA2 is a moderate penetrance gene contributing to young-onset prostate cancer: Implications for genetic testing in prostate cancer patients. Br. J. Cancer 2011, 105, 1230-1234. [CrossRef] 
51. Iqbal, J.; Ragone, A.; Lubinski, J.; Lynch, H.T.; Moller, P.; Ghadirian, P.; Foulkes, W.D.; Armel, S.; Eisen, A.; Neuhausen, S.L.; et al. The incidence of pancreatic cancer in BRCA1 and BRCA2 mutation carriers. Br. J. Cancer 2012, 107, 2005-2009. [CrossRef]

52. Moran, A.; O'Hara, C.; Khan, S.; Shack, L.; Woodward, E.; Maher, E.R.; Lalloo, F.; Evans, D.G.R. Risk of cancer other than breast or ovarian in individuals with BRCA1 and BRCA2 mutations. Fam. Cancer 2012, 11, 235-242. [CrossRef]

53. The Breast Cancer Linkage Consortium. Cancer risks in BRCA2 mutation carriers. J. Natl. Cancer Inst. 1999, 91, 1310-1316. [CrossRef] [PubMed]

54. National Comprehensive Cancer Network (NCCN) Guidelines: Genetic/Familial High-Risk Assessment: Breast, Ovarian and Pancreatic. Version 1. 2020. Available online: https://www.nccn.org/professionals/ physician_gls/pdf/genetics_bop.pdf (accessed on 7 February 2020).

55. National Comprehensive Cancer Network (NCCN) Guidelines: Prostate Cancer Early Detection. Version 2. 2019. Available online: https://www.nccn.org/professionals/physician_gls/pdf/prostate_detection.pdf (accessed on 7 February 2020).

56. Lord, C.J.; Ashworth, A. PARP inhibitors: Synthetic lethality in the clinic. Science 2017, 355, 1152-1158. [CrossRef] [PubMed]

57. Faraoni, I.; Graziani, G. Role of BRCA Mutations in Cancer Treatment with Poly (ADP-ribose) Polymerase (PARP) Inhibitors. Cancers 2018, 10, 487. [CrossRef] [PubMed]

58. Harris, C.C. Structure and function of the p53 tumor suppressor gene: Clues for rational cancer therapeutic strategies. J. Natl. Cancer Inst. 1996, 88, 1442-1455. [CrossRef]

59. Ozaki, T.; Nakagawara, A. p53: The attractive tumor suppressor in the cancer research field. J. Biomed. Biotechnol. 2011, 2011, 603925. [CrossRef]

60. Boyd, M.T.; Vlatkovic, N. p53: A molecular marker for the detection of cancer. Expert Opin. Med. Diagn. 2008, 2, 1013-1024. [CrossRef]

61. Ventura, A.; Kirsch, D.G.; McLaughlin, M.E.; Tuveson, D.A.; Grimm, J.; Lintault, L.; Newman, J.; Reczek, E.E.; Weissleder, R.; Jacks, T. Restoration of p53 function leads to tumour regression in vivo. Nature 2007, 445, 661-665. [CrossRef]

62. Li, F.P.; Fraumeni, J.F. Soft-tissue sarcomas, breast cancer, and other neoplasms. A familial syndrome? Ann. Intern. Med. 1969, 71, 747-752. [CrossRef]

63. Chompret, A.; Brugières, L.; Ronsin, M.; Gardes, M.; Dessarps-Freichey, F.; Abel, A.; Hua, D.; Ligot, L.; Dondon, M.G.; Bressac-de Paillerets, B.; et al. P53 germline mutations in childhood cancers and cancer risk for carrier individuals. Br. J. Cancer 2000, 82, 1932-1937. [PubMed]

64. Nichols, K.E.; Malkin, D.; Garber, J.E.; Fraumeni, J.F.; Li, F.P. Germ-line p53 mutations predispose to a wide spectrum of early-onset cancers. Cancer Epidemiol. Biomark. Prev. 2001, 10, 83-87.

65. Olivier, M.; Goldgar, D.E.; Sodha, N.; Ohgaki, H.; Kleihues, P.; Hainaut, P.; Eeles, R.A. Li-Fraumeni and related syndromes: Correlation between tumor type, family structure, and TP53 genotype. Cancer Res. 2003, 63, 6643-6650. [PubMed]

66. Varley, J.M. Germline TP53 mutations and Li-Fraumeni syndrome. Hum. Mutat. 2003, 21, 313-320. [CrossRef]

67. Gonzalez, K.D.; Noltner, K.A.; Buzin, C.H.; Gu, D.; Wen-Fong, C.Y.; Nguyen, V.Q.; Han, J.H.; Lowstuter, K.; Longmate, J.; Sommer, S.S.; et al. Beyond Li Fraumeni Syndrome: Clinical characteristics of families with p53 germline mutations. J. Clin. Oncol. 2009, 27, 1250-1256. [CrossRef]

68. Wong, P.; Verselis, S.J.; Garber, J.E.; Schneider, K.; DiGianni, L.; Stockwell, D.H.; Li, F.P.; Syngal, S. Prevalence of early onset colorectal cancer in 397 patients with classic Li-Fraumeni syndrome. Gastroenterology 2006, 130, 73-79. [CrossRef]

69. Masciari, S.; Dewanwala, A.; Stoffel, E.M.; Lauwers, G.Y.; Zheng, H.; Achatz, M.I.; Riegert-Johnson, D.; Foretova, L.; Silva, E.M.; Digianni, L.; et al. Gastric cancer in individuals with Li-Fraumeni syndrome. Genet. Med. 2011, 13, 651-657. [CrossRef]

70. Birch, J.M.; Alston, R.D.; McNally, R.J.; Evans, D.G.; Kelsey, A.M.; Harris, M.; Eden, O.B.; Varley, J.M. Relative frequency and morphology of cancers in carriers of germline TP53 mutations. Oncogene 2001, 20, 4621-4628. [CrossRef]

71. Masciari, S.; Dillon, D.A.; Rath, M.; Robson, M.; Weitzel, J.N.; Balmana, J.; Gruber, S.B.; Ford, J.M.; Euhus, D.; Lebensohn, A.; et al. Breast cancer phenotype in women with TP53 germline mutations: A Li-Fraumeni syndrome consortium effort. Breast Cancer Res. Treat. 2012, 133, 1125-1130. [CrossRef] 
72. Ruijs, M.W.G.; Verhoef, S.; Rookus, M.A.; Pruntel, R.; van der Hout, A.H.; Hogervorst, F.B.L.; Kluijt, I.; Sijmons, R.H.; Aalfs, C.M.; Wagner, A.; et al. TP53 germline mutation testing in 180 families suspected of Li-Fraumeni syndrome: Mutation detection rate and relative frequency of cancers in different familial phenotypes. J. Med. Genet. 2010, 47, 421-428. [CrossRef]

73. Toss, A.; Tomasello, C.; Razzaboni, E.; Contu, G.; Grandi, G.; Cagnacci, A.; Schilder, R.J.; Cortesi, L. Hereditary ovarian cancer: Not only BRCA 1 and 2 genes. Biomed. Res. Int. 2015, 2015, 341723. [CrossRef]

74. Pezzolesi, M.G.; Zbuk, K.M.; Waite, K.A.; Eng, C. Comparative genomic and functional analyses reveal a novel cis-acting PTEN regulatory element as a highly conserved functional E-box motif deleted in Cowden syndrome. Hum. Mol. Genet. 2007, 16, 1058-1071. [CrossRef] [PubMed]

75. Dillon, L.M.; Miller, T.W. Therapeutic targeting of cancers with loss of PTEN function. Curr. Drug Targets 2014, 15, 65-79. [CrossRef] [PubMed]

76. Mester, J.; Eng, C. Cowden syndrome: Recognizing and managing a not-so-rare hereditary cancer syndrome. J. Surg. Oncol. 2015, 111, 125-130. [CrossRef] [PubMed]

77. Cho, M.-Y.; Kim, H.S.; Eng, C.; Kim, D.S.; Kang, S.J.; Eom, M.; Yi, S.Y.; Bronner, M.P. First report of ovarian dysgerminoma in Cowden syndrome with germline PTEN mutation and PTEN-related 10q loss of tumor heterozygosity. Am. J. Surg. Pathol. 2008, 32, 1258-1264. [CrossRef] [PubMed]

78. Tan, M.-H.; Mester, J.L.; Ngeow, J.; Rybicki, L.A.; Orloff, M.S.; Eng, C. Lifetime cancer risks in individuals with germline PTEN mutations. Clin. Cancer Res. 2012, 18, 400-407. [CrossRef] [PubMed]

79. Ngeow, J.; Sesock, K.; Eng, C. Breast cancer risk and clinical implications for germline PTEN mutation carriers. Breast Cancer Res. Treat. 2017, 165, 1-8. [CrossRef]

80. Hobert, J.A.; Eng, C. PTEN hamartoma tumor syndrome: An overview. Genet. Med. 2009, 11, 687-694. [CrossRef]

81. Bubien, V.; Bonnet, F.; Brouste, V.; Hoppe, S.; Barouk-Simonet, E.; David, A.; Edery, P.; Bottani, A.; Layet, V.; Caron, O.; et al. High cumulative risks of cancer in patients with PTEN hamartoma tumour syndrome. J. Med. Genet. 2013, 50, 255-263. [CrossRef]

82. Ngeow, J.; Stanuch, K.; Mester, J.L.; Barnholtz-Sloan, J.S.; Eng, C. Second malignant neoplasms in patients with Cowden syndrome with underlying germline PTEN mutations. J. Clin. Oncol. 2014, 32, 1818-1824. [CrossRef]

83. Nieuwenhuis, M.H.; Kets, C.M.; Murphy-Ryan, M.; Yntema, H.G.; Evans, D.G.; Colas, C.; Møller, P.; Hes, F.J.; Hodgson, S.V.; Olderode-Berends, M.J.W.; et al. Cancer risk and genotype-phenotype correlations in PTEN hamartoma tumor syndrome. Fam. Cancer 2014, 13, 57-63. [CrossRef] [PubMed]

84. Orloff, M.S.; He, X.; Peterson, C.; Chen, F.; Chen, J.-L.; Mester, J.L.; Eng, C. Germline PIK3CA and AKT1 mutations in Cowden and Cowden-like syndromes. Am. J. Hum. Genet. 2013, 92, 76-80. [CrossRef] [PubMed]

85. Xu, X.; Jin, D.; Durgan, J.; Hall, A. LKB1 controls human bronchial epithelial morphogenesis through p114RhoGEF-dependent RhoA activation. Mol. Cell. Biol. 2013, 33, 2671-2682. [CrossRef] [PubMed]

86. Zhao, R.-X.; Xu, Z.-X. Targeting the LKB1 tumor suppressor. Curr. Drug Targets 2014, 15, 32-52. [CrossRef]

87. Lim, W.; Olschwang, S.; Keller, J.J.; Westerman, A.M.; Menko, F.H.; Boardman, L.A.; Scott, R.J.; Trimbath, J.; Giardiello, F.M.; Gruber, S.B.; et al. Relative frequency and morphology of cancers in STK11 mutation carriers. Gastroenterology 2004, 126, 1788-1794. [CrossRef]

88. Syngal, S.; Brand, R.E.; Church, J.M.; Giardiello, F.M.; Hampel, H.L.; Burt, R.W. American College of Gastroenterology ACG clinical guideline: Genetic testing and management of hereditary gastrointestinal cancer syndromes. Am. J. Gastroenterol. 2015, 110, 223-262. [CrossRef]

89. National Comprehensive Cancer Network (NCCN) Guidelines: Genetic/Familial High-Risk Assessment: Colorectal. Version 3. 2019. Available online: https://www.nccn.org/professionals/physician_gls/pdf/ genetics_colon.pdf (accessed on 7 February 2020).

90. van Roy, F.; Berx, G. The cell-cell adhesion molecule E-cadherin. Cell. Mol. Life Sci. 2008, 65, 3756-3788. [CrossRef]

91. Christofori, G.; Semb, H. The role of the cell-adhesion molecule E-cadherin as a tumour-suppressor gene. Trends Biochem. Sci. 1999, 24, 73-76. [CrossRef]

92. Frixen, U.H.; Behrens, J.; Sachs, M.; Eberle, G.; Voss, B.; Warda, A.; Löchner, D.; Birchmeier, W. E-cadherin-mediated cell-cell adhesion prevents invasiveness of human carcinoma cells. J. Cell Biol. 1991, 113, 173-185. [CrossRef] 
93. Vleminckx, K.; Vakaet, L.; Mareel, M.; Fiers, W.; van Roy, F. Genetic manipulation of E-cadherin expression by epithelial tumor cells reveals an invasion suppressor role. Cell 1991, 66, 107-119. [CrossRef]

94. Perl, A.K.; Wilgenbus, P.; Dahl, U.; Semb, H.; Christofori, G. A causal role for E-cadherin in the transition from adenoma to carcinoma. Nature 1998, 392, 190-193. [CrossRef] [PubMed]

95. Brooks-Wilson, A.R.; Kaurah, P.; Suriano, G.; Leach, S.; Senz, J.; Grehan, N.; Butterfield, Y.S.N.; Jeyes, J.; Schinas, J.; Bacani, J.; et al. Germline E-cadherin mutations in hereditary diffuse gastric cancer: Assessment of 42 new families and review of genetic screening criteria. J. Med. Genet. 2004, 41, 508-517. [CrossRef] [PubMed]

96. Kaurah, P.; MacMillan, A.; Boyd, N.; Senz, J.; De Luca, A.; Chun, N.; Suriano, G.; Zaor, S.; Van Manen, L.; Gilpin, C.; et al. Founder and recurrent $\mathrm{CDH} 1$ mutations in families with hereditary diffuse gastric cancer. JAMA 2007, 297, 2360-2372. [CrossRef] [PubMed]

97. Hansford, S.; Kaurah, P.; Li-Chang, H.; Woo, M.; Senz, J.; Pinheiro, H.; Schrader, K.A.; Schaeffer, D.F.; Shumansky, K.; Zogopoulos, G.; et al. Hereditary Diffuse Gastric Cancer Syndrome: CDH1 Mutations and Beyond. JAMA Oncol. 2015, 1, 23-32. [CrossRef]

98. Li, D.; Lo, W.; Rudloff, U. Merging perspectives: Genotype-directed molecular therapy for hereditary diffuse gastric cancer (HDGC) and E-cadherin-EGFR crosstalk. Clin. Transl. Med. 2018, 7, 7. [CrossRef]

99. Berx, G.; van Roy, F. Involvement of members of the cadherin superfamily in cancer. Cold Spring Harb. Perspect. Biol. 2009, 1, a003129. [CrossRef]

100. Corso, G.; Carvalho, J.; Marrelli, D.; Vindigni, C.; Carvalho, B.; Seruca, R.; Roviello, F.; Oliveira, C. Somatic mutations and deletions of the E-cadherin gene predict poor survival of patients with gastric cancer. J. Clin. Oncol. 2013, 31, 868-875. [CrossRef]

101. Huang, R.; Ding, P.; Yang, F. Clinicopathological significance and potential drug target of CDH1 in breast cancer: A meta-analysis and literature review. Drug Des. Dev. Ther. 2015, 9, 5277-5285.

102. Niraj, J.; Färkkilä, A.; D'Andrea, A.D. The Fanconi Anemia Pathway in Cancer. Annu. Rev. Cancer Biol. 2019, 3, 457-478. [CrossRef]

103. D'Andrea, A.D. BRCA1: A missing link in the Fanconi anemia/BRCA pathway. Cancer Discov. 2013, 3, 376-378. [CrossRef]

104. Goldgar, D.E.; Easton, D.F.; Deffenbaugh, A.M.; Monteiro, A.N.A.; Tavtigian, S.V.; Couch, F.J. Breast Cancer Information Core (BIC) Steering Committee Integrated evaluation of DNA sequence variants of unknown clinical significance: Application to BRCA1 and BRCA2. Am. J. Hum. Genet. 2004, 75, 535-544. [CrossRef] [PubMed]

105. Evers, B.; Jonkers, J. Mouse models of BRCA1 and BRCA2 deficiency: Past lessons, current understanding and future prospects. Oncogene 2006, 25, 5885-5897. [CrossRef] [PubMed]

106. Keupp, K.; Hampp, S.; Hübbel, A.; Maringa, M.; Kostezka, S.; Rhiem, K.; Waha, A.; Wappenschmidt, B.; Pujol, R.; Surrallés, J.; et al. Biallelic germline BRCA1 mutations in a patient with early onset breast cancer, mild Fanconi anemia-like phenotype, and no chromosome fragility. Mol. Genet. Genom. Med. 2019, 7, e863. [CrossRef] [PubMed]

107. Domchek, S.M.; Tang, J.; Stopfer, J.; Lilli, D.R.; Hamel, N.; Tischkowitz, M.; Monteiro, A.N.A.; Messick, T.E.; Powers, J.; Yonker, A.; et al. Biallelic deleterious BRCA1 mutations in a woman with early-onset ovarian cancer. Cancer Discov. 2013, 3, 399-405. [CrossRef] [PubMed]

108. Freire, B.L.; Homma, T.K.; Funari, M.F.A.; Lerario, A.M.; Leal, A.M.; Velloso, E.D.R.P.; Malaquias, A.C.; Jorge, A.A.L. Homozygous loss of function BRCA1 variant causing a Fanconi-anemia-like phenotype, a clinical report and review of previous patients. Eur. J. Med. Genet. 2018, 61, 130-133. [CrossRef]

109. Sawyer, S.L.; Tian, L.; Kähkönen, M.; Schwartzentruber, J.; Kircher, M.; Majewski, J.; Dyment, D.A.; Innes, A.M.; Boycott, K.M.; Moreau, L.A.; et al. Biallelic mutations in BRCA1 cause a new Fanconi anemia subtype. Cancer Discov. 2015, 5, 135-142. [CrossRef]

110. Seo, A.; Steinberg-Shemer, O.; Unal, S.; Casadei, S.; Walsh, T.; Gumruk, F.; Shalev, S.; Shimamura, A.; Akarsu, N.A.; Tamary, H.; et al. Mechanism for survival of homozygous nonsense mutations in the tumor suppressor gene BRCA1. Proc. Natl. Acad. Sci. USA 2018, 115, 5241-5246. [CrossRef]

111. Walden, H.; Deans, A.J. The Fanconi anemia DNA repair pathway: Structural and functional insights into a complex disorder. Annu. Rev. Biophys. 2014, 43, 257-278. [CrossRef] 
112. Berwick, M.; Satagopan, J.M.; Ben-Porat, L.; Carlson, A.; Mah, K.; Henry, R.; Diotti, R.; Milton, K.; Pujara, K.; Landers, T.; et al. Genetic heterogeneity among Fanconi anemia heterozygotes and risk of cancer. Cancer Res. 2007, 67, 9591-9596. [CrossRef]

113. Barroso, E.; Pita, G.; Arias, J.I.; Menendez, P.; Zamora, P.; Blanco, M.; Benitez, J.; Ribas, G. The Fanconi anemia family of genes and its correlation with breast cancer susceptibility and breast cancer features. Breast Cancer Res. Treat. 2009, 118, 655-660. [CrossRef]

114. Kiiski, J.I.; Pelttari, L.M.; Khan, S.; Freysteinsdottir, E.S.; Reynisdottir, I.; Hart, S.N.; Shimelis, H.; Vilske, S.; Kallioniemi, A.; Schleutker, J.; et al. Exome sequencing identifies FANCM as a susceptibility gene for triple-negative breast cancer. Proc. Natl. Acad. Sci. USA 2014, 111, 15172-15177. [CrossRef] [PubMed]

115. Economopoulou, P.; Dimitriadis, G.; Psyrri, A. Beyond BRCA: New hereditary breast cancer susceptibility genes. Cancer Treat. Rev. 2015, 41, 1-8. [CrossRef] [PubMed]

116. Peterlongo, P.; Catucci, I.; Colombo, M.; Caleca, L.; Mucaki, E.; Bogliolo, M.; Marin, M.; Damiola, F.; Bernard, L.; Pensotti, V.; et al. FANCM c.5791C>T nonsense mutation (rs144567652) induces exon skipping, affects DNA repair activity and is a familial breast cancer risk factor. Hum. Mol. Genet. 2015, 24, 5345-5355. [CrossRef] [PubMed]

117. Tedaldi, G.; Tebaldi, M.; Zampiga, V.; Danesi, R.; Arcangeli, V.; Ravegnani, M.; Cangini, I.; Pirini, F.; Petracci, E.; Rocca, A.; et al. Multiple-gene panel analysis in a case series of 255 women with hereditary breast and ovarian cancer. Oncotarget 2017, 8, 47064-47075. [CrossRef]

118. Silvestri, V.; Rizzolo, P.; Zelli, V.; Valentini, V.; Zanna, I.; Bianchi, S.; Tibiletti, M.G.; Varesco, L.; Russo, A.; Tommasi, S.; et al. A possible role of FANCM mutations in male breast cancer susceptibility: Results from a multicenter study in Italy. Breast 2018, 38, 92-97. [CrossRef]

119. Neidhardt, G.; Hauke, J.; Ramser, J.; Groß, E.; Gehrig, A.; Müller, C.R.; Kahlert, A.-K.; Hackmann, K.; Honisch, E.; Niederacher, D.; et al. Association Between Loss-of-Function Mutations Within the FANCM Gene and Early-Onset Familial Breast Cancer. JAMA Oncol. 2017, 3, 1245-1248. [CrossRef] [PubMed]

120. Thompson, E.R.; Doyle, M.A.; Ryland, G.L.; Rowley, S.M.; Choong, D.Y.H.; Tothill, R.W.; Thorne, H.; kConFab; Barnes, D.R.; Li, J.; et al. Exome sequencing identifies rare deleterious mutations in DNA repair genes FANCC and BLM as potential breast cancer susceptibility alleles. PLoS Genet. 2012, 8, e1002894. [CrossRef]

121. Zdzienicka, M.Z.; Arwert, F. Breast cancer and Fanconi anemia: What are the connections? Trends Mol. Med. 2002, 8, 458-460. [CrossRef]

122. Antoniou, A.C.; Casadei, S.; Heikkinen, T.; Barrowdale, D.; Pylkäs, K.; Roberts, J.; Lee, A.; Subramanian, D.; De Leeneer, K.; Fostira, F.; et al. Breast-cancer risk in families with mutations in PALB2. N. Engl. J. Med. 2014, 371, 497-506. [CrossRef]

123. Antoniou, A.C.; Foulkes, W.D.; Tischkowitz, M. Breast-cancer risk in families with mutations in PALB2: The authors reply. N. Engl. J. Med. 2014, 371, 1651-1652. [CrossRef]

124. Casadei, S.; Norquist, B.M.; Walsh, T.; Stray, S.; Mandell, J.B.; Lee, M.K.; Stamatoyannopoulos, J.A.; King, M.-C. Contribution of inherited mutations in the BRCA2-interacting protein PALB2 to familial breast cancer. Cancer Res. 2011, 71, 2222-2229. [CrossRef] [PubMed]

125. Ding, Y.C.; Steele, L.; Kuan, C.-J.; Greilac, S.; Neuhausen, S.L. Mutations in BRCA2 and PALB2 in male breast cancer cases from the United States. Breast Cancer Res. Treat. 2011, 126, 771-778. [CrossRef] [PubMed]

126. Silvestri, V.; Zelli, V.; Valentini, V.; Rizzolo, P.; Navazio, A.S.; Coppa, A.; Agata, S.; Oliani, C.; Barana, D.; Castrignanò, T; et al. Whole-exome sequencing and targeted gene sequencing provide insights into the role of PALB2 as a male breast cancer susceptibility gene. Cancer 2017, 123, 210-218. [CrossRef] [PubMed]

127. Ramus, S.J.; Song, H.; Dicks, E.; Tyrer, J.P.; Rosenthal, A.N.; Intermaggio, M.P.; Fraser, L.; Gentry-Maharaj, A.; Hayward, J.; Philpott, S.; et al. Germline Mutations in the BRIP1, BARD1, PALB2, and NBN Genes in Women With Ovarian Cancer. J. Natl. Cancer Inst. 2015, 107, 1. [CrossRef] [PubMed]

128. Jones, S.; Hruban, R.H.; Kamiyama, M.; Borges, M.; Zhang, X.; Parsons, D.W.; Lin, J.C.-H.; Palmisano, E.; Brune, K.; Jaffee, E.M.; et al. Exomic sequencing identifies PALB2 as a pancreatic cancer susceptibility gene. Science 2009, 324, 217. [CrossRef] [PubMed]

129. Slater, E.P.; Langer, P.; Niemczyk, E.; Strauch, K.; Butler, J.; Habbe, N.; Neoptolemos, J.P.; Greenhalf, W.; Bartsch, D.K. PALB2 mutations in European familial pancreatic cancer families. Clin. Genet. 2010, 78, 490-494. [CrossRef] [PubMed] 
130. Cantor, S.B.; Bell, D.W.; Ganesan, S.; Kass, E.M.; Drapkin, R.; Grossman, S.; Wahrer, D.C.; Sgroi, D.C.; Lane, W.S.; Haber, D.A.; et al. BACH1, a novel helicase-like protein, interacts directly with BRCA1 and contributes to its DNA repair function. Cell 2001, 105, 149-160. [CrossRef]

131. Cantor, S.; Drapkin, R.; Zhang, F.; Lin, Y.; Han, J.; Pamidi, S.; Livingston, D.M. The BRCA1-associated protein $\mathrm{BACH} 1$ is a DNA helicase targeted by clinically relevant inactivating mutations. Proc. Natl. Acad. Sci. USA 2004, 101, 2357-2362. [CrossRef]

132. Rafnar, T.; Gudbjartsson, D.F.; Sulem, P.; Jonasdottir, A.A.; Sigurdsson, A.; Jonasdottir, A.A.; Besenbacher, S.; Lundin, P.; Stacey, S.N.; Gudmundsson, J.; et al. Mutations in BRIP1 confer high risk of ovarian cancer. Nat. Genet. 2011, 43, 1104-1107. [CrossRef]

133. Seal, S.; Thompson, D.; Renwick, A.; Elliott, A.; Kelly, P.; Barfoot, R.; Chagtai, T.; Jayatilake, H.; Ahmed, M.; Spanova, K.; et al. Truncating mutations in the Fanconi anemia J gene BRIP1 are low-penetrance breast cancer susceptibility alleles. Nat. Genet. 2006, 38, 1239-1241. [CrossRef]

134. Easton, D.F.; Lesueur, F.; Decker, B.; Michailidou, K.; Li, J.; Allen, J.; Luccarini, C.; Pooley, K.A.; Shah, M.; Bolla, M.K.; et al. No evidence that protein truncating variants in BRIP1 are associated with breast cancer risk: Implications for gene panel testing. J. Med. Genet. 2016, 53, 298-309. [CrossRef] [PubMed]

135. Weber-Lassalle, N.; Hauke, J.; Ramser, J.; Richters, L.; Groß, E.; Blümcke, B.; Gehrig, A.; Kahlert, A.-K.; Müller, C.R.; Hackmann, K.; et al. BRIP1 loss-of-function mutations confer high risk for familial ovarian cancer, but not familial breast cancer. Breast Cancer Res. 2018, 20, 7. [CrossRef] [PubMed]

136. ClinicalTrials.gov. Identifier: NCT03344965-Olaparib in Metastatic Breast Cancer. Available online: https: //clinicaltrials.gov/ct2/show/NCT03344965 (accessed on 7 February 2020).

137. Pennington, K.P.; Walsh, T.; Harrell, M.I.; Lee, M.K.; Pennil, C.C.; Rendi, M.H.; Thornton, A.; Norquist, B.M.; Casadei, S.; Nord, A.S.; et al. Germline and somatic mutations in homologous recombination genes predict platinum response and survival in ovarian, fallopian tube, and peritoneal carcinomas. Clin. Cancer Res. 2014, 20, 764-775. [CrossRef] [PubMed]

138. Zaki-Dizaji, M.; Akrami, S.M.; Abolhassani, H.; Rezaei, N.; Aghamohammadi, A. Ataxia telangiectasia syndrome: Moonlighting ATM. Expert Rev. Clin. Immunol. 2017, 13, 1155-1172. [CrossRef] [PubMed]

139. Savitsky, K.; Bar-Shira, A.; Gilad, S.; Rotman, G.; Ziv, Y.; Vanagaite, L.; Tagle, D.A.; Smith, S.; Uziel, T.; Sfez, S.; et al. A single ataxia telangiectasia gene with a product similar to PI-3 kinase. Science 1995, 268, 1749-1753. [CrossRef] [PubMed]

140. Thompson, D.; Duedal, S.; Kirner, J.; McGuffog, L.; Last, J.; Reiman, A.; Byrd, P.; Taylor, M.; Easton, D.F. Cancer risks and mortality in heterozygous ATM mutation carriers. J. Natl. Cancer Inst. 2005, 97, 813-822. [CrossRef]

141. Renwick, A.; Thompson, D.; Seal, S.; Kelly, P.; Chagtai, T.; Ahmed, M.; North, B.; Jayatilake, H.; Barfoot, R.; Spanova, K.; et al. ATM mutations that cause ataxia-telangiectasia are breast cancer susceptibility alleles. Nat. Genet. 2006, 38, 873-875. [CrossRef]

142. Goldgar, D.E.; Healey, S.; Dowty, J.G.; Da Silva, L.; Chen, X.; Spurdle, A.B.; Terry, M.B.; Daly, M.J.; Buys, S.M.; Southey, M.C.; et al. Rare variants in the ATM gene and risk of breast cancer. Breast Cancer Res. 2011, 13, R73. [CrossRef]

143. Marabelli, M.; Cheng, S.-C.; Parmigiani, G. Penetrance of ATM Gene Mutations in Breast Cancer: A Meta-Analysis of Different Measures of Risk. Genet. Epidemiol. 2016, 40, 425-431. [CrossRef]

144. Van Os, N.J.H.; Roeleveld, N.; Weemaes, C.M.R.; Jongmans, M.C.J.; Janssens, G.O.; Taylor, A.M.R.; Hoogerbrugge, N.; Willemsen, M.A.A.P. Health risks for ataxia-telangiectasia mutated heterozygotes: A systematic review, meta-analysis and evidence-based guideline. Clin. Genet. 2016, 90, 105-117. [CrossRef]

145. Tavtigian, S.V.; Oefner, P.J.; Babikyan, D.; Hartmann, A.; Healey, S.; Le Calvez-Kelm, F.; Lesueur, F.; Byrnes, G.B.; Chuang, S.-C.; Forey, N.; et al. Rare, evolutionarily unlikely missense substitutions in ATM confer increased risk of breast cancer. Am. J. Hum. Genet. 2009, 85, 427-446. [CrossRef] [PubMed]

146. Cremona, C.A.; Behrens, A. ATM signalling and cancer. Oncogene 2014, 33, 3351-3360. [CrossRef] [PubMed]

147. Hirao, A.; Cheung, A.; Duncan, G.; Girard, P.-M.; Elia, A.J.; Wakeham, A.; Okada, H.; Sarkissian, T.; Wong, J.A.; Sakai, T.; et al. Chk2 is a tumor suppressor that regulates apoptosis in both an ataxia telangiectasia mutated (ATM)-dependent and an ATM-independent manner. Mol. Cell. Biol. 2002, 22, 6521-6532. [CrossRef] [PubMed]

148. Matsuoka, S.; Huang, M.; Elledge, S.J. Linkage of ATM to cell cycle regulation by the Chk2 protein kinase. Science 1998, 282, 1893-1897. [CrossRef] 
149. Chehab, N.H.; Malikzay, A.; Appel, M.; Halazonetis, T.D. Chk2/hCds1 functions as a DNA damage checkpoint in G1 by stabilizing p53. Genes Dev. 2000, 14, 278-288.

150. Lee, J.S.; Collins, K.M.; Brown, A.L.; Lee, C.H.; Chung, J.H. hCds1-mediated phosphorylation of BRCA1 regulates the DNA damage response. Nature 2000, 404, 201-204. [CrossRef]

151. Yang, S.; Kuo, C.; Bisi, J.E.; Kim, M.K. PML-dependent apoptosis after DNA damage is regulated by the checkpoint kinase hCds1/Chk2. Nat. Cell Biol. 2002, 4, 865-870. [CrossRef]

152. Bell, D.W.; Varley, J.M.; Szydlo, T.E.; Kang, D.H.; Wahrer, D.C.; Shannon, K.E.; Lubratovich, M.; Verselis, S.J.; Isselbacher, K.J.; Fraumeni, J.F.; et al. Heterozygous germ line hCHK2 mutations in Li-Fraumeni syndrome. Science 1999, 286, 2528-2531. [CrossRef]

153. Vahteristo, P.; Tamminen, A.; Karvinen, P.; Eerola, H.; Eklund, C.; Aaltonen, L.A.; Blomqvist, C.; Aittomäki, K.; Nevanlinna, H. p53, CHK2, and CHK1 genes in Finnish families with Li-Fraumeni syndrome: Further evidence of CHK2 in inherited cancer predisposition. Cancer Res. 2001, 61, 5718-5722.

154. Evans, D.G.; Birch, J.M.; Narod, S.A. Is CHEK2 a cause of the Li-Fraumeni syndrome? J. Med. Genet. 2008, 45, 63-64. [CrossRef]

155. Adank, M.A.; Jonker, M.A.; Kluijt, I.; van Mil, S.E.; Oldenburg, R.A.; Mooi, W.J.; Hogervorst, F.B.L.; van den Ouweland, A.M.W.; Gille, J.J.P.; Schmidt, M.K.; et al. CHEK2*1100delC homozygosity is associated with a high breast cancer risk in women. J. Med. Genet. 2011, 48, 860-863. [CrossRef] [PubMed]

156. Walsh, T.; Casadei, S.; Coats, K.H.; Swisher, E.; Stray, S.M.; Higgins, J.; Roach, K.C.; Mandell, J.; Lee, M.K.; Ciernikova, S.; et al. Spectrum of mutations in BRCA1, BRCA2, CHEK2, and TP53 in families at high risk of breast cancer. JAMA 2006, 295, 1379-1388. [CrossRef] [PubMed]

157. Desrichard, A.; Bidet, Y.; Uhrhammer, N.; Bignon, Y.-J. CHEK2 contribution to hereditary breast cancer in non-BRCA families. Breast Cancer Res. 2011, 13, R119. [CrossRef] [PubMed]

158. Tedaldi, G.; Danesi, R.; Zampiga, V.; Tebaldi, M.; Bedei, L.; Zoli, W.; Amadori, D.; Falcini, F.; Calistri, D. First evidence of a large CHEK2 duplication involved in cancer predisposition in an Italian family with hereditary breast cancer. BMC Cancer 2014, 14, 478. [CrossRef] [PubMed]

159. Meijers-Heijboer, H.; van den Ouweland, A.; Klijn, J.; Wasielewski, M.; de Snoo, A.; Oldenburg, R.; Hollestelle, A.; Houben, M.; Crepin, E.; van Veghel-Plandsoen, M.; et al. Low-penetrance susceptibility to breast cancer due to $\mathrm{CHEK} 2\left({ }^{*}\right) 1100 \mathrm{delC}$ in noncarriers of BRCA1 or BRCA2 mutations. Nat. Genet. 2002, 31, 55-59. [PubMed]

160. Weischer, M.; Bojesen, S.E.; Ellervik, C.; Tybjaerg-Hansen, A.; Nordestgaard, B.G. CHEK2*1100delC genotyping for clinical assessment of breast cancer risk: Meta-analyses of 26,000 patient cases and 27,000 controls. J. Clin. Oncol. 2008, 26, 542-548. [CrossRef]

161. CHEK2 Breast Cancer Case-Control Consortium CHEK2*1100delC and susceptibility to breast cancer: A collaborative analysis involving 10,860 breast cancer cases and 9,065 controls from 10 studies. Am. J. Hum. Genet. 2004, 74, 1175-1182. [CrossRef]

162. Bernstein, J.L.; Teraoka, S.N.; John, E.M.; Andrulis, I.L.; Knight, J.A.; Lapinski, R.; Olson, E.R.; Wolitzer, A.L.; Seminara, D.; Whittemore, A.S.; et al. The CHEK2*1100delC allelic variant and risk of breast cancer: Screening results from the Breast Cancer Family Registry. Cancer Epidemiol. Biomarkers Prev. 2006, 15, 348-352. [CrossRef]

163. Weischer, M.; Bojesen, S.E.; Tybjaerg-Hansen, A.; Axelsson, C.K.; Nordestgaard, B.G. Increased risk of breast cancer associated with CHEK2*1100delC. J. Clin. Oncol. 2007, 25, 57-63. [CrossRef]

164. Cybulski, C.; Górski, B.; Huzarski, T.; Masojć, B.; Mierzejewski, M.; Debniak, T.; Teodorczyk, U.; Byrski, T.; Gronwald, J.; Matyjasik, J.; et al. CHEK2 is a multiorgan cancer susceptibility gene. Am. J. Hum. Genet. 2004, 75, 1131-1135. [CrossRef]

165. Dong, X.; Wang, L.; Taniguchi, K.; Wang, X.; Cunningham, J.M.; McDonnell, S.K.; Qian, C.; Marks, A.F.; Slager, S.L.; Peterson, B.J.; et al. Mutations in CHEK2 associated with prostate cancer risk. Am. J. Hum. Genet. 2003, 72, 270-280. [CrossRef] [PubMed]

166. Cybulski, C.; Huzarski, T.; Górski, B.; Masojć, B.; Mierzejewski, M.; Debniak, T.; Gliniewicz, B.; Matyjasik, J.; Złowocka, E.; Kurzawski, G.; et al. A novel founder CHEK2 mutation is associated with increased prostate cancer risk. Cancer Res. 2004, 64, 2677-2679. [CrossRef] [PubMed]

167. Cybulski, C.; Wokołorczyk, D.; Huzarski, T.; Byrski, T.; Gronwald, J.; Górski, B.; Debniak, T.; Masojć, B.; Jakubowska, A.; Gliniewicz, B.; et al. A large germline deletion in the Chek2 kinase gene is associated with an increased risk of prostate cancer. J. Med. Genet. 2006, 43, 863-866. [CrossRef] [PubMed] 
168. Meijers-Heijboer, H.; Wijnen, J.; Vasen, H.; Wasielewski, M.; Wagner, A.; Hollestelle, A.; Elstrodt, F.; van den Bos, R.; de Snoo, A.; Fat, G.T.A.; et al. The CHEK2 1100delC mutation identifies families with a hereditary breast and colorectal cancer phenotype. Am. J. Hum. Genet. 2003, 72, 1308-1314. [CrossRef]

169. Teodorczyk, U.; Cybulski, C.; Wokołorczyk, D.; Jakubowska, A.; Starzyńska, T.; Lawniczak, M.; Domagała, P.; Ferenc, K.; Marlicz, K.; Banaszkiewicz, Z.; et al. The risk of gastric cancer in carriers of CHEK2 mutations. Fam. Cancer 2013, 12, 473-478. [CrossRef]

170. Szymanska-Pasternak, J.; Szymanska, A.; Medrek, K.; Imyanitov, E.N.; Cybulski, C.; Gorski, B.; Magnowski, P.; Dziuba, I.; Gugala, K.; Debniak, B.; et al. CHEK2 variants predispose to benign, borderline and low-grade invasive ovarian tumors. Gynecol. Oncol. 2006, 102, 429-431. [CrossRef]

171. Lawrenson, K.; Iversen, E.S.; Tyrer, J.; Weber, R.P.; Concannon, P.; Hazelett, D.J.; Li, Q.; Marks, J.R.; Berchuck, A.; Lee, J.M.; et al. Common variants at the CHEK2 gene locus and risk of epithelial ovarian cancer. Carcinogenesis 2015, 36, 1341-1353. [CrossRef]

172. Baysal, B.E.; DeLoia, J.A.; Willett-Brozick, J.E.; Goodman, M.T.; Brady, M.F.; Modugno, F.; Lynch, H.T.; Conley, Y.P.; Watson, P.; Gallion, H.H. Analysis of CHEK2 gene for ovarian cancer susceptibility. Gynecol. Oncol. 2004, 95, 62-69. [CrossRef]

173. Krylova, N.Y.; Ponomariova, D.N.; Sherina, N.Y.; Ogorodnikova, N.Y.; Logvinov, D.A.; Porhanova, N.V.; Lobeiko, O.S.; Urmancheyeva, A.F.; Maximov, S.Y.; Togo, A.V.; et al. CHEK2 1100 delC mutation in Russian ovarian cancer patients. Hered. Cancer Clin. Pract. 2007, 5, 153-156. [CrossRef]

174. Ow, G.S.; Ivshina, A.V.; Fuentes, G.; Kuznetsov, V.A. Identification of two poorly prognosed ovarian carcinoma subtypes associated with CHEK2 germ-line mutation and non-CHEK2 somatic mutation gene signatures. Cell Cycle 2014, 13, 2262-2280. [CrossRef]

175. Williams, L.H.; Choong, D.; Johnson, S.A.; Campbell, I.G. Genetic and epigenetic analysis of CHEK2 in sporadic breast, colon, and ovarian cancers. Clin. Cancer Res. 2006, 12, 6967-6972. [CrossRef] [PubMed]

176. Wu, L.C.; Wang, Z.W.; Tsan, J.T.; Spillman, M.A.; Phung, A.; Xu, X.L.; Yang, M.C.; Hwang, L.Y.; Bowcock, A.M.; Baer, R. Identification of a RING protein that can interact in vivo with the BRCA1 gene product. Nat. Genet. 1996, 14, 430-440. [CrossRef] [PubMed]

177. Shakya, R.; Szabolcs, M.; McCarthy, E.; Ospina, E.; Basso, K.; Nandula, S.; Murty, V.; Baer, R.; Ludwig, T. The basal-like mammary carcinomas induced by Brca1 or Bard1 inactivation implicate the BRCA1/BARD1 heterodimer in tumor suppression. Proc. Natl. Acad. Sci. USA 2008, 105, 7040-7045. [CrossRef] [PubMed]

178. Ghimenti, C.; Sensi, E.; Presciuttini, S.; Brunetti, I.M.; Conte, P.; Bevilacqua, G.; Caligo, M.A. Germline mutations of the BRCA1-associated ring domain (BARD1) gene in breast and breast/ovarian families negative for BRCA1 and BRCA2 alterations. Genes Chromosom. Cancer 2002, 33, 235-242. [CrossRef] [PubMed]

179. Ratajska, M.; Antoszewska, E.; Piskorz, A.; Brozek, I.; Borg, Å.; Kusmierek, H.; Biernat, W.; Limon, J. Cancer predisposing BARD1 mutations in breast-ovarian cancer families. Breast Cancer Res. Treat. 2012, 131, 89-97. [CrossRef] [PubMed]

180. Walsh, T.; Lee, M.K.; Casadei, S.; Thornton, A.M.; Stray, S.M.; Pennil, C.; Nord, A.S.; Mandell, J.B.; Swisher, E.M.; King, M.-C. Detection of inherited mutations for breast and ovarian cancer using genomic capture and massively parallel sequencing. Proc. Natl. Acad. Sci. USA 2010, 107, 12629-12633. [CrossRef] [PubMed]

181. Walker, L.C.; Lattimore, V.L.; Kvist, A.; Kleiblova, P.; Zemankova, P.; de Jong, L.; Wiggins, G.A.R.; Hakkaart, C.; Cree, S.L.; Behar, R.; et al. Comprehensive Assessment of BARD1 Messenger Ribonucleic Acid Splicing With Implications for Variant Classification. Front. Genet. 2019, 10, 1139. [CrossRef]

182. Suszynska, M.; Kluzniak, W.; Wokolorczyk, D.; Jakubowska, A.; Huzarski, T.; Gronwald, J.; Debniak, T.; Szwiec, M.; Ratajska, M.; Klonowska, K.; et al. BARD1 is A Low/Moderate Breast Cancer Risk Gene: Evidence Based on An Association Study of the Central European p.Q564X Recurrent Mutation. Cancers 2019, 11, 740. [CrossRef]

183. Thai, T.H.; Du, F.; Tsan, J.T.; Jin, Y.; Phung, A.; Spillman, M.A.; Massa, H.F.; Muller, C.Y.; Ashfaq, R.; Mathis, J.M.; et al. Mutations in the BRCA1-associated RING domain (BARD1) gene in primary breast, ovarian and uterine cancers. Hum. Mol. Genet. 1998, 7, 195-202. [CrossRef]

184. Kawabata, M.; Kawabata, T.; Nishibori, M. Role of recA/RAD51 family proteins in mammals. Acta Med. Okayama 2005, 59, 1-9. 
185. Chun, J.; Buechelmaier, E.S.; Powell, S.N. Rad51 paralog complexes BCDX2 and CX3 act at different stages in the BRCA1-BRCA2-dependent homologous recombination pathway. Mol. Cell. Biol. 2013, 33, 387-395. [CrossRef]

186. Golmard, L.; Castéra, L.; Krieger, S.; Moncoutier, V.; Abidallah, K.; Tenreiro, H.; Laugé, A.; Tarabeux, J.; Millot, G.A.; Nicolas, A.; et al. Contribution of germline deleterious variants in the RAD51 paralogs to breast and ovarian cancers. Eur. J. Hum. Genet. 2017, 25, 1345-1353. [CrossRef] [PubMed]

187. Kato, M.; Yano, K.; Matsuo, F.; Saito, H.; Katagiri, T.; Kurumizaka, H.; Yoshimoto, M.; Kasumi, F.; Akiyama, F.; Sakamoto, G.; et al. Identification of Rad51 alteration in patients with bilateral breast cancer. J. Hum. Genet. 2000, 45, 133-137. [CrossRef] [PubMed]

188. Prakash, R.; Zhang, Y.; Feng, W.; Jasin, M. Homologous recombination and human health: The roles of BRCA1, BRCA2, and associated proteins. Cold Spring Harb. Perspect. Biol. 2015, 7, a016600. [CrossRef] [PubMed]

189. Park, D.J.; Lesueur, F.; Nguyen-Dumont, T.; Pertesi, M.; Odefrey, F.; Hammet, F.; Neuhausen, S.L.; John, E.M.; Andrulis, I.L.; Terry, M.B.; et al. Rare mutations in XRCC2 increase the risk of breast cancer. Am. J. Hum. Genet. 2012, 90, 734-739. [CrossRef] [PubMed]

190. Hilbers, F.S.; Wijnen, J.T.; Hoogerbrugge, N.; Oosterwijk, J.C.; Collee, M.J.; Peterlongo, P.; Radice, P.; Manoukian, S.; Feroce, I.; Capra, F.; et al. Rare variants in XRCC2 as breast cancer susceptibility alleles. J. Med. Genet. 2012, 49, 618-620. [CrossRef] [PubMed]

191. Pelttari, L.M.; Kiiski, J.I.; Ranta, S.; Vilske, S.; Blomqvist, C.; Aittomäki, K.; Nevanlinna, H. RAD51, XRCC3, and XRCC2 mutation screening in Finnish breast cancer families. Springerplus 2015, 4, 92. [CrossRef]

192. He, X.-F.; Wei, W.; Su, J.; Yang, Z.-X.; Liu, Y.; Zhang, Y.; Ding, D.-P.; Wang, W. Association between the XRCC3 polymorphisms and breast cancer risk: Meta-analysis based on case-control studies. Mol. Biol. Rep. 2012, 39, 5125-5134. [CrossRef]

193. Yuan, C.; Liu, X.; Yan, S.; Wang, C.; Kong, B. Analyzing association of the XRCC3 gene polymorphism with ovarian cancer risk. Biomed Res. Int. 2014, 2014, 648137. [CrossRef]

194. Lin, W.-Y.; Camp, N.J.; Cannon-Albright, L.A.; Allen-Brady, K.; Balasubramanian, S.; Reed, M.W.R.; Hopper, J.L.; Apicella, C.; Giles, G.G.; Southey, M.C.; et al. A role for XRCC2 gene polymorphisms in breast cancer risk and survival. J. Med. Genet. 2011, 48, 477-484. [CrossRef]

195. Meindl, A.; Hellebrand, H.; Wiek, C.; Erven, V.; Wappenschmidt, B.; Niederacher, D.; Freund, M.; Lichtner, P.; Hartmann, L.; Schaal, H.; et al. Germline mutations in breast and ovarian cancer pedigrees establish RAD51C as a human cancer susceptibility gene. Nat. Genet. 2010, 42, 410-414. [CrossRef] [PubMed]

196. Braybrooke, J.P.; Spink, K.G.; Thacker, J.; Hickson, I.D. The RAD51 family member, RAD51L3, is a DNA-stimulated ATPase that forms a complex with XRCC2. J. Biol. Chem. 2000, 275, 29100-29106. [CrossRef] [PubMed]

197. Rupnik, A.; Grenon, M.; Lowndes, N. The MRN complex. Curr. Biol. 2008, 18, R455-R457. [CrossRef] [PubMed]

198. Bartkova, J.; Tommiska, J.; Oplustilova, L.; Aaltonen, K.; Tamminen, A.; Heikkinen, T.; Mistrik, M.; Aittomäki, K.; Blomqvist, C.; Heikkilä, P.; et al. Aberrations of the MRE11-RAD50-NBS1 DNA damage sensor complex in human breast cancer: MRE11 as a candidate familial cancer-predisposing gene. Mol. Oncol. 2008, 2, 296-316. [CrossRef] [PubMed]

199. Bogdanova, N.; Feshchenko, S.; Schürmann, P.; Waltes, R.; Wieland, B.; Hillemanns, P.; Rogov, Y.I.; Dammann, O.; Bremer, M.; Karstens, J.H.; et al. Nijmegen Breakage Syndrome mutations and risk of breast cancer. Int. J. Cancer 2008, 122, 802-806. [CrossRef] [PubMed]

200. Damiola, F.; Pertesi, M.; Oliver, J.; Le Calvez-Kelm, F.; Voegele, C.; Young, E.L.; Robinot, N.; Forey, N.; Durand, G.; Vallée, M.P.; et al. Rare key functional domain missense substitutions in MRE11A, RAD50, and NBN contribute to breast cancer susceptibility: Results from a Breast Cancer Family Registry case-control mutation-screening study. Breast Cancer Res. 2014, 16, R58. [CrossRef] [PubMed]

201. Heikkinen, K.; Karppinen, S.-M.; Soini, Y.; Mäkinen, M.; Winqvist, R. Mutation screening of Mre11 complex genes: Indication of RAD50 involvement in breast and ovarian cancer susceptibility. J. Med. Genet. 2003, 40, e131. [CrossRef]

202. Varon, R.; Vissinga, C.; Platzer, M.; Cerosaletti, K.M.; Chrzanowska, K.H.; Saar, K.; Beckmann, G.; Seemanová, E.; Cooper, P.R.; Nowak, N.J.; et al. Nibrin, a novel DNA double-strand break repair protein, is mutated in Nijmegen breakage syndrome. Cell 1998, 93, 467-476. [CrossRef] 
203. Waltes, R.; Kalb, R.; Gatei, M.; Kijas, A.W.; Stumm, M.; Sobeck, A.; Wieland, B.; Varon, R.; Lerenthal, Y.; Lavin, M.F.; et al. Human RAD50 deficiency in a Nijmegen breakage syndrome-like disorder. Am. J. Hum. Genet. 2009, 84, 605-616. [CrossRef]

204. Matsumoto, Y.; Miyamoto, T.; Sakamoto, H.; Izumi, H.; Nakazawa, Y.; Ogi, T.; Tahara, H.; Oku, S.; Hiramoto, A.; Shiiki, T.; et al. Two unrelated patients with MRE11A mutations and Nijmegen breakage syndrome-like severe microcephaly. DNA Repair (Amst) 2011, 10, 314-321. [CrossRef]

205. Cybulski, C.; Górski, B.; Debniak, T.; Gliniewicz, B.; Mierzejewski, M.; Masojć, B.; Jakubowska, A.; Matyjasik, J.; Złowocka, E.; Sikorski, A.; et al. NBS1 is a prostate cancer susceptibility gene. Cancer Res. 2004, 64, 1215-1219. [CrossRef] [PubMed]

206. Steffen, J.; Varon, R.; Mosor, M.; Maneva, G.; Maurer, M.; Stumm, M.; Nowakowska, D.; Rubach, M.; Kosakowska, E.; Ruka, W.; et al. Increased cancer risk of heterozygotes with NBS1 germline mutations in Poland. Int. J. Cancer 2004, 111, 67-71. [CrossRef] [PubMed]

207. Ciara, E.; Piekutowska-Abramczuk, D.; Popowska, E.; Grajkowska, W.; Barszcz, S.; Perek, D.; Dembowska-Bagińska, B.; Perek-Polnik, M.; Kowalewska, E.; Czajńska, A.; et al. Heterozygous germ-line mutations in the NBN gene predispose to medulloblastoma in pediatric patients. Acta Neuropathol. 2010, 119, 325-334. [CrossRef] [PubMed]

208. Seemanová, E.; Jarolim, P.; Seeman, P.; Varon, R.; Digweed, M.; Swift, M.; Sperling, K. Cancer risk of heterozygotes with the NBN founder mutation. J. Natl. Cancer Inst. 2007, 99, 1875-1880. [CrossRef] [PubMed]

209. Meyer, P.; Stapelmann, H.; Frank, B.; Varon, R.; Burwinkel, B.; Schmitt, C.; Boettger, M.B.; Klaes, R.; Sperling, K.; Hemminki, K.; et al. Molecular genetic analysis of NBS1 in German melanoma patients. Melanoma Res. 2007, 17, 109-116. [CrossRef] [PubMed]

210. Górski, B.; Debniak, T.; Masojć, B.; Mierzejewski, M.; Medrek, K.; Cybulski, C.; Jakubowska, A.; Kurzawski, G.; Chosia, M.; Scott, R.; et al. Germline 657del5 mutation in the NBS1 gene in breast cancer patients. Int. J. Cancer 2003, 106, 379-381. [CrossRef] [PubMed]

211. Debniak, T.; Górski, B.; Cybulski, C.; Jakubowska, A.; Kurzawski, G.; Lener, M.; Mierzejewski, M.; Masojć, B.; Medrek, K.; Kładny, J.; et al. Germline 657del5 mutation in the NBS1 gene in patients with malignant melanoma of the skin. Melanoma Res. 2003, 13, 365-370. [CrossRef]

212. Kurian, A.W.; Hughes, E.; Handorf, E.A.; Gutin, A.; Allen, B.; Hartman, A.-R.; Hall, M.J. Breast and Ovarian Cancer Penetrance Estimates Derived From Germline Multiple-Gene Sequencing Results in Women. JCO Precis. Oncol. 2017, 1-12. [CrossRef]

213. Park, D.J.; Tao, K.; Le Calvez-Kelm, F.; Nguyen-Dumont, T.; Robinot, N.; Hammet, F.; Odefrey, F.; Tsimiklis, H.; Teo, Z.L.; Thingholm, L.B.; et al. Rare mutations in RINT1 predispose carriers to breast and Lynch syndrome-spectrum cancers. Cancer Discov. 2014, 4, 804-815. [CrossRef]

214. Xiao, J.; Liu, C.C.; Chen, P.L.; Lee, W.H. RINT-1, a novel Rad50-interacting protein, participates in radiation-induced G(2)/M checkpoint control. J. Biol. Chem. 2001, 276, 6105-6111. [CrossRef]

215. Chung, D.C.; Rustgi, A.K. DNA mismatch repair and cancer. Gastroenterology 1995, 109, 1685-1699. [CrossRef]

216. Tutlewska, K.; Lubinski, J.; Kurzawski, G. Germline deletions in the EPCAM gene as a cause of Lynch syndrome-literature review. Hered. Cancer Clin. Pract. 2013, 11, 9. [CrossRef] [PubMed]

217. Iyer, R.R.; Pluciennik, A.; Burdett, V.; Modrich, P.L. DNA mismatch repair: Functions and mechanisms. Chem. Rev. 2006, 106, 302-323. [CrossRef] [PubMed]

218. Bonadona, V.; Bonaïti, B.; Olschwang, S.; Grandjouan, S.; Huiart, L.; Longy, M.; Guimbaud, R.; Buecher, B.; Bignon, Y.-J.; Caron, O.; et al. Cancer risks associated with germline mutations in MLH1, MSH2, and MSH6 genes in Lynch syndrome. JAMA 2011, 305, 2304-2310. [CrossRef]

219. Giardiello, F.M.; Allen, J.I.; Axilbund, J.E.; Boland, C.R.; Burke, C.A.; Burt, R.W.; Church, J.M.; Dominitz, J.A.; Johnson, D.A.; Kaltenbach, T.; et al. Guidelines on genetic evaluation and management of Lynch syndrome: A consensus statement by the US Multi-society Task Force on colorectal cancer. Am. J. Gastroenterol. 2014, 109, 1159-1179. [CrossRef]

220. Ketabi, Z.; Bartuma, K.; Bernstein, I.; Malander, S.; Grönberg, H.; Björck, E.; Holck, S.; Nilbert, M. Ovarian cancer linked to Lynch syndrome typically presents as early-onset, non-serous epithelial tumors. Gynecol. Oncol. 2011, 121, 462-465. [CrossRef] 
221. Engel, C.; Loeffler, M.; Steinke, V.; Rahner, N.; Holinski-Feder, E.; Dietmaier, W.; Schackert, H.K.; Goergens, H.; von Knebel Doeberitz, M.; Goecke, T.O.; et al. Risks of less common cancers in proven mutation carriers with Lynch syndrome. J. Clin. Oncol. 2012, 30, 4409-4415. [CrossRef]

222. Win, A.K.; Lindor, N.M.; Jenkins, M.A. Risk of breast cancer in Lynch syndrome: A systematic review. Breast Cancer Res. 2013, 15, R27. [CrossRef]

223. Harkness, E.F.; Barrow, E.; Newton, K.; Green, K.; Clancy, T.; Lalloo, F.; Hill, J.; Evans, D.G. Lynch syndrome caused by MLH1 mutations is associated with an increased risk of breast cancer: A cohort study. J. Med. Genet. 2015, 52, 553-556. [CrossRef]

224. ten Broeke, S.W.; Brohet, R.M.; Tops, C.M.; van der Klift, H.M.; Velthuizen, M.E.; Bernstein, I.; Capellá Munar, G.; Gomez Garcia, E.; Hoogerbrugge, N.; Letteboer, T.G.W.; et al. Lynch syndrome caused by germline PMS2 mutations: Delineating the cancer risk. J. Clin. Oncol. 2015, 33, 319-325. [CrossRef]

225. Risinger, J.I.; Barrett, J.C.; Watson, P.; Lynch, H.T.; Boyd, J. Molecular genetic evidence of the occurrence of breast cancer as an integral tumor in patients with the hereditary nonpolyposis colorectal carcinoma syndrome. Cancer 1996, 77, 1836-1843. [CrossRef]

226. Gruber, S.B.; Petersen, G.M. Cancer risks in BRCA1 carriers: Time for the next generation of studies. J. Natl. Cancer Inst. 2002, 94, 1344-1345. [CrossRef] [PubMed]

227. Müller, A.; Edmonston, T.B.; Corao, D.A.; Rose, D.G.; Palazzo, J.P.; Becker, H.; Fry, R.D.; Rueschoff, J.; Fishel, R. Exclusion of breast cancer as an integral tumor of hereditary nonpolyposis colorectal cancer. Cancer Res. 2002, 62, 1014-1019. [PubMed]

228. Walsh, M.D.; Buchanan, D.D.; Cummings, M.C.; Pearson, S.-A.; Arnold, S.T.; Clendenning, M.; Walters, R.; McKeone, D.M.; Spurdle, A.B.; Hopper, J.L.; et al. Lynch syndrome-associated breast cancers: Clinicopathologic characteristics of a case series from the colon cancer family registry. Clin. Cancer Res. 2010, 16, 2214-2224. [CrossRef]

229. Burn, J.; Bishop, D.T.; Mecklin, J.-P.; Macrae, F.; Möslein, G.; Olschwang, S.; Bisgaard, M.-L.; Ramesar, R.; Eccles, D.; Maher, E.R.; et al. Effect of aspirin or resistant starch on colorectal neoplasia in the Lynch syndrome. N. Engl. J. Med. 2008, 359, 2567-2578. [CrossRef]

230. Le, D.T.; Uram, J.N.; Wang, H.; Bartlett, B.R.; Kemberling, H.; Eyring, A.D.; Skora, A.D.; Luber, B.S.; Azad, N.S.; Laheru, D.; et al. PD-1 Blockade in Tumors with Mismatch-Repair Deficiency. N. Engl. J. Med. 2015, 372, 2509-2520. [CrossRef]

231. Zhao, P.; Li, L.; Jiang, X.; Li, Q. Mismatch repair deficiency/microsatellite instability-high as a predictor for anti-PD-1/PD-L1 immunotherapy efficacy. J. Hematol. Oncol. 2019, 12, 54. [CrossRef]

232. Germano, G.; Amirouchene-Angelozzi, N.; Rospo, G.; Bardelli, A. The Clinical Impact of the Genomic Landscape of Mismatch Repair-Deficient Cancers. Cancer Discov. 2018, 8, 1518-1528. [CrossRef]

233. Pal, T.; Permuth-Wey, J.; Sellers, T.A. A review of the clinical relevance of mismatch-repair deficiency in ovarian cancer. Cancer 2008, 113, 733-742. [CrossRef]

234. Zhao, C.; Li, S.; Zhao, M.; Zhu, H.; Zhu, X. Prognostic values of DNA mismatch repair genes in ovarian cancer patients treated with platinum-based chemotherapy. Arch. Gynecol. Obstet. 2018, 297, 153-159. [CrossRef]

235. Trovó-Marqui, A.B.; Tajara, E.H. Neurofibromin: A general outlook. Clin. Genet. 2006, 70, 1-13. [CrossRef] [PubMed]

236. DeClue, J.E.; Papageorge, A.G.; Fletcher, J.A.; Diehl, S.R.; Ratner, N.; Vass, W.C.; Lowy, D.R. Abnormal regulation of mammalian p21ras contributes to malignant tumor growth in von Recklinghausen (type 1) neurofibromatosis. Cell 1992, 69, 265-273. [CrossRef]

237. Basu, T.N.; Gutmann, D.H.; Fletcher, J.A.; Glover, T.W.; Collins, F.S.; Downward, J. Aberrant regulation of ras proteins in malignant tumour cells from type 1 neurofibromatosis patients. Nature 1992, 356, 713-715. [CrossRef] [PubMed]

238. Madanikia, S.A.; Bergner, A.; Ye, X.; Blakeley, J.O. Increased risk of breast cancer in women with NF1. Am. J. Med. Genet. A 2012, 158A, 3056-3060. [CrossRef] [PubMed]

239. Wang, X.; Levin, A.M.; Smolinski, S.E.; Vigneau, F.D.; Levin, N.K.; Tainsky, M.A. Breast cancer and other neoplasms in women with neurofibromatosis type 1: A retrospective review of cases in the Detroit metropolitan area. Am. J. Med. Genet. A 2012, 158A, 3061-3064. [CrossRef] [PubMed]

240. Seminog, O.O.; Goldacre, M.J. Age-specific risk of breast cancer in women with neurofibromatosis type 1. Br. J. Cancer 2015, 112, 1546-1548. [CrossRef] [PubMed] 
241. Sharif, S.; Moran, A.; Huson, S.M.; Iddenden, R.; Shenton, A.; Howard, E.; Evans, D.G.R. Women with neurofibromatosis 1 are at a moderately increased risk of developing breast cancer and should be considered for early screening. J. Med. Genet. 2007, 44, 481-484. [CrossRef]

242. Evans, D.G.R.; O'Hara, C.; Wilding, A.; Ingham, S.L.; Howard, E.; Dawson, J.; Moran, A.; Scott-Kitching, V.; Holt, F.; Huson, S.M. Mortality in neurofibromatosis 1: In North West England: An assessment of actuarial survival in a region of the UK since 1989. Eur. J. Hum. Genet. 2011, 19, 1187-1191. [CrossRef]

243. Howell, S.J.; Hockenhull, K.; Salih, Z.; Evans, D.G. Increased risk of breast cancer in neurofibromatosis type 1: Current insights. Breast Cancer 2017, 9, 531-536. [CrossRef]

244. Dischinger, P.S.; Tovar, E.A.; Essenburg, C.J.; Madaj, Z.B.; Gardner, E.E.; Callaghan, M.E.; Turner, A.N.; Challa, A.K.; Kempston, T.; Eagleson, B.; et al. NF1 deficiency correlates with estrogen receptor signaling and diminished survival in breast cancer. NPJ Breast Cancer 2018, 4, 29. [CrossRef]

245. Jessen, W.J.; Miller, S.J.; Jousma, E.; Wu, J.; Rizvi, T.A.; Brundage, M.E.; Eaves, D.; Widemann, B.; Kim, M.-O.; Dombi, E.; et al. MEK inhibition exhibits efficacy in human and mouse neurofibromatosis tumors. J. Clin. Investig. 2013, 123, 340-347. [CrossRef] [PubMed]

246. Cunniff, C.; Bassetti, J.A.; Ellis, N.A. Bloom's Syndrome: Clinical Spectrum, Molecular Pathogenesis, and Cancer Predisposition. Mol. Syndromol. 2017, 8, 4-23. [CrossRef] [PubMed]

247. Cunniff, C.; Djavid, A.R.; Carrubba, S.; Cohen, B.; Ellis, N.A.; Levy, C.F.; Jeong, S.; Lederman, H.M.; Vogiatzi, M.; Walsh, M.F.; et al. Health supervision for people with Bloom syndrome. Am. J. Med. Genet. A 2018, 176, 1872-1881. [CrossRef] [PubMed]

248. Tavera-Tapia, A.; de la Hoya, M.; Calvete, O.; Martin-Gimeno, P.; Fernández, V.; Macías, J.A.; Alonso, B.; Pombo, L.; de Diego, C.; Alonso, R.; et al. RECQL5: Another DNA helicase potentially involved in hereditary breast cancer susceptibility. Hum. Mutat. 2019, 40, 566-577. [CrossRef] [PubMed]

249. Cybulski, C.; Carrot-Zhang, J.; Kluźniak, W.; Rivera, B.; Kashyap, A.; Wokołorczyk, D.; Giroux, S.; Nadaf, J.; Hamel, N.; Zhang, S.; et al. Germline RECQL mutations are associated with breast cancer susceptibility. Nat. Genet. 2015, 47, 643-646. [CrossRef]

250. Shahi, R.B.; De Brakeleer, S.; Caljon, B.; Pauwels, I.; Bonduelle, M.; Joris, S.; Fontaine, C.; Vanhoeij, M.; Van Dooren, S.; Teugels, E.; et al. Identification of candidate cancer predisposing variants by performing whole-exome sequencing on index patients from BRCA1 and BRCA2-negative breast cancer families. BMC Cancer 2019, 19, 313. [CrossRef]

251. Lauper, J.M.; Krause, A.; Vaughan, T.L.; Monnat, R.J. Spectrum and risk of neoplasia in Werner syndrome: A systematic review. PLoS ONE 2013, 8, e59709. [CrossRef]

252. Zhu, X.; Chen, H.; Yang, Y.; Xu, C.; Zhou, J.; Zhou, J.; Chen, Y. Distinct prognosis of mRNA expression of the five RecQ DNA-helicase family members-RECQL, BLM, WRN, RECQL4, and RECQL5-in patients with breast cancer. Cancer Manag. Res. 2018, 10, 6649-6668. [CrossRef]

253. Bogdanova, N.; Togo, A.V.; Ratajska, M.; Kluźniak, W.; Takhirova, Z.; Tarp, T.; Prokofyeva, D.; Bermisheva, M.; Yanus, G.A.; Gorodnova, T.V.; et al. Prevalence of the BLM nonsense mutation, p.Q548X, in ovarian cancer patients from Central and Eastern Europe. Fam. Cancer 2015, 14, 145-149. [CrossRef]

254. German, J.; Sanz, M.M.; Ciocci, S.; Ye, T.Z.; Ellis, N.A. Syndrome-causing mutations of the BLM gene in persons in the Bloom's Syndrome Registry. Hum. Mutat. 2007, 28, 743-753. [CrossRef]

255. Flanagan, M.; Cunniff, C.M. Bloom Syndrome. In GeneReviews; Adam, M.P., Ardinger, H.H., Pagon, R.A., Eds.; University of Washington: Seattle, WA, USA, 2006; [Updated 2019]. Available online: https://www.ncbi. nlm.nih.gov/books/NBK1398 (accessed on 7 February 2020).

256. Oshima, J.; Martin, G.M.; Hisama, F.M. Werner Syndrome. In GeneReviews; Adam, M.P., Ardinger, H.H., Pagon, R.A., Eds.; University of Washington: Seattle, WA, USA, 2002; [Updated 2016]. Available online: https://www.ncbi.nlm.nih.gov/books/NBK1514 (accessed on 7 February 2020).

257. Wang, L.L.; Plon, S.E. Rothmund-Thomson Syndrome. In GeneReviews; Adam, M.P., Ardinger, H.H., Pagon, R.A., Eds.; University of Washington: Seattle, WA, USA, 1999; [Updated 2019]. Available online: https://www.ncbi.nlm.nih.gov/books/NBK1237 (accessed on 7 February 2020).

258. Wang, B.; Matsuoka, S.; Ballif, B.A.; Zhang, D.; Smogorzewska, A.; Gygi, S.P.; Elledge, S.J. Abraxas and RAP80 form a BRCA1 protein complex required for the DNA damage response. Science 2007, 316, 1194-1198. [CrossRef] [PubMed] 
259. Solyom, S.; Aressy, B.; Pylkäs, K.; Patterson-Fortin, J.; Hartikainen, J.M.; Kallioniemi, A.; Kauppila, S.; Nikkilä, J.; Kosma, V.-M.; Mannermaa, A.; et al. Breast cancer-associated Abraxas mutation disrupts nuclear localization and DNA damage response functions. Sci. Transl. Med. 2012, 4, 122-123. [CrossRef]

260. Akbari, M.R.; Ghadirian, P.; Robidoux, A.; Foumani, M.; Sun, Y.; Royer, R.; Zandvakili, I.; Lynch, H.; Narod, S.A. Germline RAP80 mutations and susceptibility to breast cancer. Breast Cancer Res. Treat. 2009, 113, 377-381. [CrossRef] [PubMed]

261. Ruark, E.; Snape, K.; Humburg, P.; Loveday, C.; Bajrami, I.; Brough, R.; Rodrigues, D.N.; Renwick, A.; Seal, S.; Ramsay, E.; et al. Mosaic PPM1D mutations are associated with predisposition to breast and ovarian cancer. Nature 2013, 493, 406-410. [CrossRef] [PubMed]

262. Vijai, J.; Topka, S.; Villano, D.; Ravichandran, V.; Maxwell, K.N.; Maria, A.; Thomas, T.; Gaddam, P.; Lincoln, A.; Kazzaz, S.; et al. A Recurrent ERCC3 Truncating Mutation Confers Moderate Risk for Breast Cancer. Cancer Discov. 2016, 6, 1267-1275. [CrossRef] [PubMed]

263. Coupier, I.; Cousin, P.-Y.; Hughes, D.; Legoix-Né, P.; Trehin, A.; Sinilnikova, O.M.; Stoppa-Lyonnet, D. BAP1 and breast cancer risk. Fam. Cancer 2005, 4, 273-277. [CrossRef] [PubMed]

264. Pilarski, R.; Cebulla, C.M.; Massengill, J.B.; Rai, K.; Rich, T.; Strong, L.; McGillivray, B.; Asrat, M.-J.; Davidorf, F.H.; Abdel-Rahman, M.H. Expanding the clinical phenotype of hereditary BAP1 cancer predisposition syndrome, reporting three new cases. Genes. Chromosom. Cancer 2014, 53, 177-182. [CrossRef] [PubMed]

265. Belhadj, S.; Mur, P.; Navarro, M.; González, S.; Moreno, V.; Capellá, G.; Valle, L. Delineating the Phenotypic Spectrum of the NTHL1-Associated Polyposis. Clin. Gastroenterol. Hepatol. 2017, 15, 461-462. [CrossRef]

266. Grolleman, J.E.; de Voer, R.M.; Elsayed, F.A.; Nielsen, M.; Weren, R.D.A.; Palles, C.; Ligtenberg, M.J.L.; Vos, J.R.; Ten Broeke, S.W.; de Miranda, N.F.C.C.; et al. Mutational Signature Analysis Reveals NTHL1 Deficiency to Cause a Multi-tumor Phenotype. Cancer Cell 2019, 35, 256-266. [CrossRef]

267. Huang, K.-L.; Mashl, R.J.; Wu, Y.; Ritter, D.I.; Wang, J.; Oh, C.; Paczkowska, M.; Reynolds, S.; Wyczalkowski, M.A.; Oak, N.; et al. Pathogenic Germline Variants in 10,389 Adult Cancers. Cell 2018, 173, 355-370. [CrossRef]

268. Weaver, J.M.; Edwards, P.A. Targeted next-generation sequencing for routine clinical screening of mutations. Genome Med. 2011, 3, 58. [CrossRef] [PubMed]

269. Gracia-Aznarez, F.J.; Fernandez, V.; Pita, G.; Peterlongo, P.; Dominguez, O.; de la Hoya, M.; Duran, M.; Osorio, A.; Moreno, L.; Gonzalez-Neira, A.; et al. Whole exome sequencing suggests much of non-BRCA1/BRCA2 familial breast cancer is due to moderate and low penetrance susceptibility alleles. PLoS ONE 2013, 8, e55681. [CrossRef] [PubMed]

270. Kurian, A.W.; Hare, E.E.; Mills, M.A.; Kingham, K.E.; McPherson, L.; Whittemore, A.S.; McGuire, V.; Ladabaum, U.; Kobayashi, Y.; Lincoln, S.E.; et al. Clinical evaluation of a multiple-gene sequencing panel for hereditary cancer risk assessment. J. Clin. Oncol. 2014, 32, 2001-2009. [CrossRef] [PubMed]

271. Desmond, A.; Kurian, A.W.; Gabree, M.; Mills, M.A.; Anderson, M.J.; Kobayashi, Y.; Horick, N.; Yang, S.; Shannon, K.M.; Tung, N.; et al. Clinical Actionability of Multigene Panel Testing for Hereditary Breast and Ovarian Cancer Risk Assessment. JAMA Oncol. 2015, 1, 943-951. [CrossRef]

272. Kraus, C.; Hoyer, J.; Vasileiou, G.; Wunderle, M.; Lux, M.P.; Fasching, P.A.; Krumbiegel, M.; Uebe, S.; Reuter, M.; Beckmann, M.W.; et al. Gene panel sequencing in familial breast/ovarian cancer patients identifies multiple novel mutations also in genes others than BRCA1/2. Int. J. Cancer 2017, 140, 95-102. [CrossRef]

273. Stoffel, E.M.; Koeppe, E.; Everett, J.; Ulintz, P.; Kiel, M.; Osborne, J.; Williams, L.; Hanson, K.; Gruber, S.B.; Rozek, L.S. Germline Genetic Features of Young Individuals With Colorectal Cancer. Gastroenterology 2018, 154, 897-905. [CrossRef]

274. Plichta, J.K.; Griffin, M.; Thakuria, J.; Hughes, K.S. What's New in Genetic Testing for Cancer Susceptibility? Oncology 2016, 30, 787-799.

275. Adams, D.R.; Eng, C.M. Next-Generation Sequencing to Diagnose Suspected Genetic Disorders. N. Engl. J. Med. 2018, 379, 1353-1362. [CrossRef]

276. Robson, M.E.; Bradbury, A.R.; Arun, B.; Domchek, S.M.; Ford, J.M.; Hampel, H.L.; Lipkin, S.M.; Syngal, S.; Wollins, D.S.; Lindor, N.M. American Society of Clinical Oncology Policy Statement Update: Genetic and Genomic Testing for Cancer Susceptibility. J. Clin. Oncol. 2015, 33, 3660-3667. [CrossRef]

277. Aronson, S.J.; Rehm, H.L. Building the foundation for genomics in precision medicine. Nature 2015, 526, 336-342. [CrossRef] 
278. Antoniou, A.C.; Pharoah, P.P.D.; Smith, P.; Easton, D.F. The BOADICEA model of genetic susceptibility to breast and ovarian cancer. Br. J. Cancer 2004, 91, 1580-1590. [CrossRef] [PubMed]

279. Parmigiani, G.; Berry, D.; Aguilar, O. Determining carrier probabilities for breast cancer-susceptibility genes BRCA1 and BRCA2. Am. J. Hum. Genet. 1998, 62, 145-158. [CrossRef] [PubMed]

280. Frank, T.S.; Deffenbaugh, A.M.; Reid, J.E.; Hulick, M.; Ward, B.E.; Lingenfelter, B.; Gumpper, K.L.; Scholl, T.; Tavtigian, S.V.; Pruss, D.R.; et al. Clinical characteristics of individuals with germline mutations in BRCA1 and BRCA2: Analysis of 10,000 individuals. J. Clin. Oncol. 2002, 20, 1480-1490. [CrossRef] [PubMed]

281. Evans, D.G.R.; Eccles, D.M.; Rahman, N.; Young, K.; Bulman, M.; Amir, E.; Shenton, A.; Howell, A.; Lalloo, F. A new scoring system for the chances of identifying a BRCA1/2 mutation outperforms existing models including BRCAPRO. J. Med. Genet. 2004, 41, 474-480. [CrossRef]

282. Tyrer, J.; Duffy, S.W.; Cuzick, J. A breast cancer prediction model incorporating familial and personal risk factors. Stat. Med. 2004, 23, 1111-1130. [CrossRef]

283. Euhus, D.M.; Smith, K.C.; Robinson, L.; Stucky, A.; Olopade, O.I.; Cummings, S.; Garber, J.E.; Chittenden, A.; Mills, G.B.; Rieger, P.; et al. Pretest prediction of BRCA1 or BRCA2 mutation by risk counselors and the computer model BRCAPRO. J. Natl. Cancer Inst. 2002, 94, 844-851. [CrossRef]

284. De la Hoya, M.; Díez, O.; Pérez-Segura, P.; Godino, J.; Fernández, J.M.; Sanz, J.; Alonso, C.; Baiget, M.; Díaz-Rubio, E.; Caldés, T. Pre-test prediction models of BRCA1 or BRCA2 mutation in breast/ovarian families attending familial cancer clinics. J. Med. Genet. 2003, 40, 503-510. [CrossRef]

285. Li, X.; You, R.; Wang, X.; Liu, C.; Xu, Z.; Zhou, J.; Yu, B.; Xu, T.; Cai, H.; Zou, Q. Effectiveness of Prophylactic Surgeries in BRCA1 or BRCA2 Mutation Carriers: A Meta-analysis and Systematic Review. Clin. Cancer Res. 2016, 22, 3971-3981. [CrossRef]

286. Celentano, V.; Luglio, G.; Antonelli, G.; Tarquini, R.; Bucci, L. Prophylactic surgery in Lynch syndrome. Tech. Coloproctol. 2011, 15, 129-134. [CrossRef]

287. Blair, V.; Martin, I.; Shaw, D.; Winship, I.; Kerr, D.; Arnold, J.; Harawira, P.; McLeod, M.; Parry, S.; Charlton, A.; et al. Hereditary diffuse gastric cancer: Diagnosis and management. Clin. Gastroenterol. Hepatol. 2006, 4, 262-275. [CrossRef]

288. Fong, P.C.; Boss, D.S.; Yap, T.A.; Tutt, A.; Wu, P.; Mergui-Roelvink, M.; Mortimer, P.; Swaisland, H.; Lau, A.; O'Connor, M.J.; et al. Inhibition of poly(ADP-ribose) polymerase in tumors from BRCA mutation carriers. $N$. Engl. J. Med. 2009, 361, 123-134. [CrossRef] [PubMed]

289. Sandhu, S.K.; Schelman, W.R.; Wilding, G.; Moreno, V.; Baird, R.D.; Miranda, S.; Hylands, L.; Riisnaes, R.; Forster, M.; Omlin, A.; et al. The poly(ADP-ribose) polymerase inhibitor niraparib (MK4827) in BRCA mutation carriers and patients with sporadic cancer: A phase 1 dose-escalation trial. Lancet Oncol. 2013, 14, 882-892. [CrossRef]

290. Audeh, M.W.; Carmichael, J.; Penson, R.T.; Friedlander, M.; Powell, B.; Bell-McGuinn, K.M.; Scott, C.; Weitzel, J.N.; Oaknin, A.; Loman, N.; et al. Oral poly (ADP-ribose) polymerase inhibitor olaparib in patients with BRCA1 or BRCA2 mutations and recurrent ovarian cancer: A proof-of-concept trial. Lancet 2010, 376, 245-251. [CrossRef]

291. Tutt, A.; Robson, M.; Garber, J.E.; Domchek, S.M.; Audeh, M.W.; Weitzel, J.N.; Friedlander, M.; Arun, B.; Loman, N.; Schmutzler, R.K.; et al. Oral poly (ADP-ribose) polymerase inhibitor olaparib in patients with BRCA1 or BRCA2 mutations and advanced breast cancer: A proof-of-concept trial. Lancet 2010, 376, 235-244. [CrossRef]

292. Sandhu, S.K.; Omlin, A.; Hylands, L.; Miranda, S.; Barber, L.J.; Riisnaes, R.; Reid, A.H.; Attard, G.; Chen, L.; Kozarewa, I.; et al. Poly (ADP-ribose) polymerase (PARP) inhibitors for the treatment of advanced germline BRCA2 mutant prostate cancer. Ann. Oncol. 2013, 24, 1416-1418. [CrossRef]

293. Golan, T.; Hammel, P.; Reni, M.; Van Cutsem, E.; Macarulla, T.; Hall, M.J.; Park, J.-O.; Hochhauser, D.; Arnold, D.; Oh, D.-Y.; et al. Maintenance Olaparib for Germline BRCA-Mutated Metastatic Pancreatic Cancer. N. Engl. J. Med. 2019, 381, 317-327. [CrossRef]

294. Hodgson, D.R.; Dougherty, B.A.; Lai, Z.; Fielding, A.; Grinsted, L.; Spencer, S.; O'Connor, M.J.; Ho, T.W.; Robertson, J.D.; Lanchbury, J.S.; et al. Candidate biomarkers of PARP inhibitor sensitivity in ovarian cancer beyond the BRCA genes. Br. J. Cancer 2018, 119, 1401-1409. [CrossRef]

295. Li, A.; Geyer, F.C.; Blecua, P.; Lee, J.Y.; Selenica, P.; Brown, D.N.; Pareja, F.; Lee, S.S.K.; Kumar, R.; Rivera, B.; et al. Homologous recombination DNA repair defects in PALB2-associated breast cancers. NPJ Breast Cancer 2019, 5, 23. [CrossRef] 
296. Konstantinopoulos, P.A.; Spentzos, D.; Karlan, B.Y.; Taniguchi, T.; Fountzilas, E.; Francoeur, N.; Levine, D.A.; Cannistra, S.A. Gene expression profile of BRCAness that correlates with responsiveness to chemotherapy and with outcome in patients with epithelial ovarian cancer. J. Clin. Oncol. 2010, 28, 3555-3561. [CrossRef]

297. Mateo, J.; Lord, C.J.; Serra, V.; Tutt, A.; Balmaña, J.; Castroviejo-Bermejo, M.; Cruz, C.; Oaknin, A.; Kaye, S.B.; de Bono, J.S. A decade of clinical development of PARP inhibitors in perspective. Ann. Oncol. 2019, 30, 1437-1447. [CrossRef]

298. Alexandrov, L.B.; Nik-Zainal, S.; Wedge, D.C.; Aparicio, S.A.J.R.; Behjati, S.; Biankin, A.V.; Bignell, G.R.; Bolli, N.; Borg, A.; Børresen-Dale, A.-L.; et al. Signatures of mutational processes in human cancer. Nature 2013, 500, 415-421. [CrossRef] [PubMed]

299. Kim, Y.-H.; Song, Y.; Kim, J.-K.; Kim, T.-M.; Sim, H.W.; Kim, H.-L.; Jang, H.; Kim, Y.-W.; Hong, K.-M. False-negative errors in next-generation sequencing contribute substantially to inconsistency of mutation databases. PLoS ONE 2019, 14, e0222535. [CrossRef] [PubMed]

300. Strom, S.P.; Lee, H.; Das, K.; Vilain, E.; Nelson, S.F.; Grody, W.W.; Deignan, J.L. Assessing the necessity of confirmatory testing for exome-sequencing results in a clinical molecular diagnostic laboratory. Genet. Med. 2014, 16, 510-515. [CrossRef] [PubMed]

301. Richards, S.; Aziz, N.; Bale, S.; Bick, D.; Das, S.; Gastier-Foster, J.; Grody, W.W.; Hegde, M.; Lyon, E.; Spector, E.; et al. Standards and guidelines for the interpretation of sequence variants: A joint consensus recommendation of the American College of Medical Genetics and Genomics and the Association for Molecular Pathology. Genet. Med. 2015, 17, 405-424. [CrossRef]

302. Thusberg, J.; Vihinen, M. Pathogenic or not? And if so, then how? Studying the effects of missense mutations using bioinformatics methods. Hum. Mutat. 2009, 30, 703-714. [CrossRef]

303. Taylor, A.; Brady, A.F.; Frayling, I.M.; Hanson, H.; Tischkowitz, M.; Turnbull, C.; Side, L. UK Cancer Genetics Group (UK-CGG) Consensus for genes to be included on cancer panel tests offered by UK genetics services: Guidelines of the UK Cancer Genetics Group. J. Med. Genet. 2018, 55, 372-377. [CrossRef]

304. Nielsen, S.M.; Eccles, D.M.; Romero, I.L.; Al-Mulla, F.; Balmaña, J.; Biancolella, M.; Bslok, R.; Caligo, M.A.; Calvello, M.; Capone, G.L.; et al. Genetic Testing and Clinical Management Practices for Variants in Non-BRCA1/2 Breast (and Breast/Ovarian) Cancer Susceptibility Genes: An International Survey by the Evidence-Based Network for the Interpretation of Germline Mutant Alleles (ENIGMA) Clinica. JCO Precis. Oncol. 2018, 2, 1-42.

305. Lu, H.-M.; Li, S.; Black, M.H.; Lee, S.; Hoiness, R.; Wu, S.; Mu, W.; Huether, R.; Chen, J.; Sridhar, S.; et al. Association of Breast and Ovarian Cancers With Predisposition Genes Identified by Large-Scale Sequencing. JAMA Oncol. 2019, 5, 51-57. [CrossRef]

306. Couch, F.J.; Shimelis, H.; Hu, C.; Hart, S.N.; Polley, E.C.; Na, J.; Hallberg, E.; Moore, R.; Thomas, A.; Lilyquist, J.; et al. Associations Between Cancer Predisposition Testing Panel Genes and Breast Cancer. JAMA Oncol. 2017, 3, 1190-1196. [CrossRef]

(C) 2020 by the authors. Licensee MDPI, Basel, Switzerland. This article is an open access article distributed under the terms and conditions of the Creative Commons Attribution (CC BY) license (http://creativecommons.org/licenses/by/4.0/). 